\title{
AN OVERVIEW ON BOTRYTIZED WINES
}

\author{
REVISÃO: VINHOS BOTRITIZADOS
}

\author{
Georgios Kallitsounakis ${ }^{1}$, Sofia Catarino ${ }^{1,2 *}$ \\ ${ }^{1}$ LEAF (Linking Landscape Environment Agriculture and Food) Research Center, Instituto Superior de Agronomia, Universidade de Lisboa, \\ Tapada da Ajuda, 1349-017 Lisboa, Portugal. \\ ${ }^{2}$ CeFEMA (Centre of Physics and Engineering of Advanced Materials) Research Center, Instituto Superior Técnico, Universidade de Lisboa, Av. \\ Rovisco Pais, 1, 1049-001 Lisboa, Portugal. \\ * Corresponding author: Tel.: +351 21 3653246, e-mail: sofiacatarino@isa.ulisboa.pt
}

(Received 08.06.2020. Accepted 29.08.2020)

\section{SUMMARY}

Noble rot wine is a specific type of sweet wine that derives from the infection of grape berries by a fungus called Botrytis cinerea. These wines are produced in specific wine regions around the world, with Sauternes region of France and Tokay region of Hungary being the most famous ones. The purpose of the current article is to provide a systematic review on the different stages of botrytized wines production, including a detailed analysis of the technical aspects involved. Specifically, it describes the process and development of berry infection by $B$. cinerea, and special emphasis is given to the main stages and operations of winemaking, conservation, aging and stabilization. A complex combination of a number of parameters (e.g., very specific environmental conditions) explains the rarity of noble rot occurrence and highlights the uniqueness of botrytized wines.

\section{RESUMO}

Os vinhos botritizados representam uma categoria específica de vinhos doces, sendo obtidos a partir de bagos de uva infectados pelo fungo Botrytis cinerea, através de um processo designado por podridão nobre. Estes vinhos são produzidos em regiões específicas do mundo, sendo Sauternes e Tokay, originários de França e Hungria respectivamente, os exemplos mais conhecidos a nível mundial. No presente trabalho são revistos os principais aspectos relacionados com a produção de vinhos botritizados. É descrito o processo e desenvolvimento da infecção do bago por $B$. cinerea, e discutidas as principais etapas e operações de vinificação, conservação, envelhecimento e estabilização. A combinação complexa de muitos factores, desde logo a exigência de condições ambientais muito específicas, explica a raridade da ocorrência de podridão nobre e destaca a singularidade deste tipo de vinhos.

Key words: Botrytization, Botrytis cinerea, noble rot, sweet wines.

Palavras-chave: Botritização, Botrytis cinerea, podridão nobre, vinhos doces.

\section{INTRODUCTION}

According to the International Organisation of Vine and Wine (OIV), noble rot wines are included in the general category of "Special Wines". "Special wines" are wines coming from fresh grapes, from musts or wines that have undergone certain treatments during or after their production and whose characteristics come not only from the grape itself, but also from the production technique used. This category includes flor or film wines, liqueur wines, sparkling wines, carbonated wines, sweet wines with residual sugar derived from grapes and icewine - eiswein (OIV, 2020).
The subcategory of "Sweet wines with residual sugar derived from grapes", where noble rot wines are included, respects wines with a content of fermentation residual sugars, glucose plus fructose, above or equal to $45 \mathrm{~g} / \mathrm{L}$. These wines result exclusively from partial alcoholic fermentation (ALF) of grapes or grape must for which the sugar content was obtained naturally during the grape maturation, or may be obtained from overripe or slightly raisined or suffering from noble rot grapes, by means of raisining, selective sorting of grapes and cryoselection. The actual alcoholic strength by volume of the wine must not be less than $4.5 \%$ vol. The potential alcoholic strength of the grapes before 
fermentation must not be less than $15 \%$ vol. (OIV, 2020).

Within the European (EU) legislation, noble rot wine integrates the category of "Wine of overripe grapes", respecting the following requisites: a) is produced without enrichment; b) has a natural alcoholic strength of more than $15 \%$ vol.; and c) has a total alcoholic strength of not less than $15 \%$ vol. and an actual alcoholic strength of not less than $12 \%$ vol. (EEC, 2013).

\section{Noble rot wines}

One of the main techniques to produce a sweet wine is by concentrating the grape juice during noble rot infection. The latter, refers to the development of the fungus Botrytis cinerea on mature grapes under very specific weather conditions (Jackson, 2008). Few rainy days after grapes ripening are vital for $B$. cinerea germination and colonization on berries. Sequential sunny days with foggy mornings and high humidity followed by afternoons with high temperatures are perfect for fungus development, water evaporation and berry's volume concentration (Keller, 2015). The attack of this fungus via microfissures, generates a modification on berry's chemical composition and leads to grape epidermis rupture and excess water losses (Carrascosa et al., 2011). The stage where the infection is visible to the naked eye is called pourri plein, while when the grape is at a stage known as pourri rôti, berry is shriveled and the sugar concentration is at maximum level (Figure 1). Due to asynchrony of fungus infection harvest takes place manually with parallel sorting on the vineyard, assuring that only well concentrated berries in the final stage of fungus development will end up in the winery (Thakur, 2018).

\section{History}

Many are the theories for the region where accidental production of this type of sweet wine took place for the first time. One possibility is that it happened in Tokaj of Hungary, where the first reports dated back to 1560 (Thakur, 2018). Another possible region, is Schloss Johannisberg of Germany in 1775, in which the winemakers were allowed to harvest only after the permission of the owner who forgot it. As a result, the harvest was very late leading to development of $B$. cinerea on grapes (Thakur, 2018). Finally, in 1815 when the two Coalition armies invaded in Paris, late harvest and botrytization occurred (Keller, 2015).

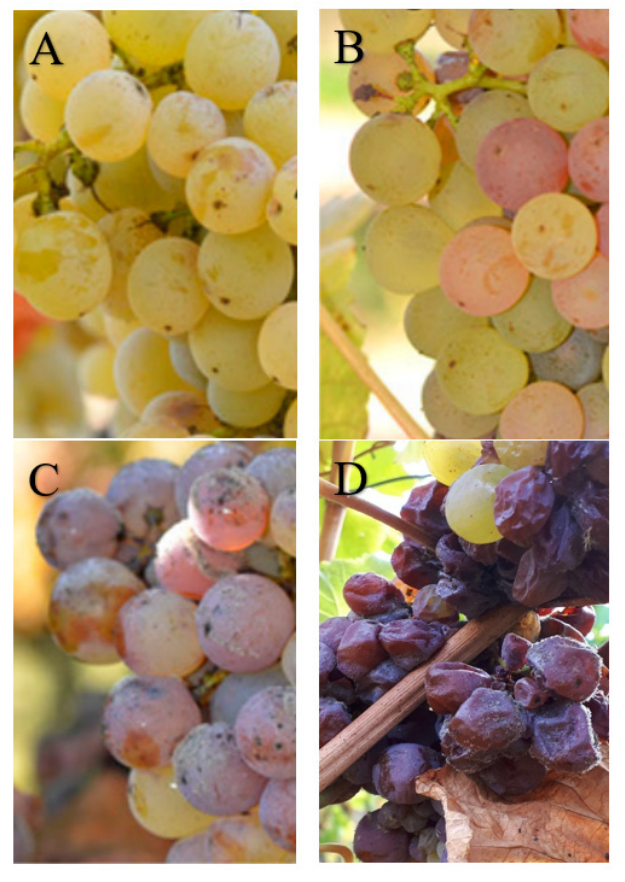

Figure 1. Stages of botrytization in the 'Semillon' variety. Healthy stage (A), mild infection (B), pourri plein (C), and pourri rôti (D) (Blanco-Ulate et al., 2015) (Photo courtesy of Château la Varière, Brissac-Quincé, France).

Estádios do processo de botritização na variedade 'Semillon'. Sem infecção aparente (A), infecção ligeira (B), pourri plein (C) ), e pourri rôti (D) (Blanco-Ulate et al., 2015) (Foto cedida por Château la Varière, Brissac-Quincé, França). 


\section{Types of noble rot wines}

Only in some specific wine regions, mainly in Sauternes, Barsac, Loupiac, Anjou and Alsace in France, Moselle in Germany, and Tokaj in Hungary, $B$. cinerea can colonize on mature grapes resulting in concentration of compounds in berries that increase their qualitative characteristics (Magyar, 2011). The most well-known wines from these regions where botrytization process has positive effects are called 'Sauternes', 'Barsac' and 'Côteaux du Layon' (France), 'Tokaji Aszú' (Hungary), 'Beerenauslese' and 'Trockenbeerenauslese' (Germany and Austria) (Magyar, 2011).

\section{Main grape varieties used for noble rot wine} production

Vitis vinifera L. cv. 'Semillon', 'Sauvignon Blanc', 'Chenin Blanc', 'Furmint', 'Riesling', 'Picolit', 'Pinot Blanc' and 'Gewürztraminer' are the main varieties used according to the region individually or as blend for botrytized wines (Jackson, 2008). Their specific characteristics, such as berry's skin thickness
(> $150 \mu \mathrm{m})$ and oenological parameters, such as potential alcohol, sugar content and acidity, make them dominant varieties for the production of this category of wines (Ribéreau-Gayon et al., 2006a). Table I displays typical analytical characteristics of noble rot wines produced with some of these grape varieties. Even though there is no direct correlation between the clone of each variety and specific qualitative markers that could indicate the quality of botrytization and so the quality of the wine, the clone of each variety seems to play a pivotal role in the relation between host and parasite (Ribéreau-Gayon et al., 2006a). Clone sensitivity to $B$. cinerea is related to berry's defense mechanism against infection (secreted substances), and clone's morphological characteristics such as berry's skin thickness and number of stomata present on berries that due their degeneration over the time will create peristomatic openings facilitating the infection (Thakur, 2018).

Table I

Analytical characteristics of noble rot wines from different French regions (Magyar, 2011)

Características analíticas de vinhos botritizados de diferentes regiões Francesas (Magyar, 2011)

\begin{tabular}{|c|c|c|c|}
\hline & $\begin{array}{c}\text { Sauternes and } \\
\text { Barsac }\end{array}$ & $\begin{array}{l}\text { Coteaux du Layon / } \\
\text { Coteaux de } \\
\text { l'Aubance }\end{array}$ & Alsace \\
\hline Grape variety & $\begin{array}{c}\text { 'Semillon', } \\
\text { 'Sauvignon Blanc', } \\
\text { 'Muscat Blanc' }\end{array}$ & 'Chenin Blanc' & $\begin{array}{c}\text { 'Gewürztraminer', } \\
\text { 'Pinot Gris' / 'Riesling', } \\
\text { 'Muscat Blanc' }\end{array}$ \\
\hline Minimum must sugar content $(\mathrm{g} / \mathrm{L})$ & 221 & 294 & $279 / 256$ \\
\hline Typical must sugar content (g/L) & $300-350$ & $350-400$ & $250-350$ \\
\hline Typical wine sugar content (g/L) & $50-150$ & $50-150$ & $50-150$ \\
\hline Minimum alcoholic strength (\% vol.) & 12 & $11-12 / 11$ & \\
\hline Typical alcohol content (\% vol.) & $13-14$ & $11.5-13$ & $12-13$ \\
\hline Typical total acidity (g/L of tartaric acid) & $6-8$ & $7-9$ & $7-10$ \\
\hline
\end{tabular}

\section{BOTRYTIS CINEREA}

\section{Biology of $B$. cinerea and life cycle}

B. cinerea Pers. Fr. [teleomorph Botryotinia fuckeliana (de Bary) Whetzel] is an ascomycete necrotrophic pathogen from the Kingdom of Fungi, Phylum Ascomycota, Subphylum Pezizomycotina, Class Leotiomycetes, Order Helotiales, Family Sclerotiniaceae, and Genus Botryotinia (Williamson et al., 2007). Its reproductivity is mainly asexually and very rare sexually. Fungus overwinters on canes as a compact mass of hardened mycelium or sclerotia able to survive in extreme environmental conditions. It has a very short period of germination in optimal conditions (Carrascosa et al., 2011). During spring or summer after the development of conidiophores, conidium can disperse and infect flower caps and pistils during flowering. After a quiescence phase, colonization on the berries just after veraison, with 
the first visible signs in-between veraison and maturity, leads to early mold known as bunch rot. When the colonization takes place just before maturity and the first visible signs appear on grapes during maturity, the infection is then called noble rot (Carrascosa et al., 2011). Several cycles of infection can happen during the season starting from the period in-between flowering and veraison until late maturation during middle of autumn (Thakur, 2018). Temperature between $15{ }^{\circ} \mathrm{C}$ and $25^{\circ} \mathrm{C}$ and humidity above $90 \%$ for more than four hours are optimal conditions for conidium germination. Berries become more susceptible as they mature and varieties with compact thin-skin clusters are easily infected (Thakur, 2018).

\section{Difference between noble and gray rot}

In many cases, during the first stages of botrytization both gray and noble rot can be observed. An infection considered as beneficial in the beginning, is possible to turn to gray mold promoting grape spoilage. This is in accordance to water availability on berry at the first stages of $B$. cinerea colonization, in which high water activity $\left(\mathrm{a}_{\mathrm{w}}\right)$ close to 0.93 is beneficial for germination and mycelia development (Rousseau and Donèche, 2001). Extended humidity and heavy precipitations promote bunch rot occurrence and prolonged survival of $B$. cinerea in the berry under the presence of other microorganisms. When $a_{w}$ is between 0.96 and 0.99 , humidity on berries increases bacterial load, promoting thus the chemical alternation of infected grapes in an unfavorable way. This co-infection leads to sugar degradation below $230 \mathrm{~g} / \mathrm{L}$, tartaric and malic acids elimination and secretion of pathogens' metabolites, making impossible the production of wine without defects. On the contrary, limited humidity during morning dew with hot afternoons, cause fast berry's water evaporation, berry's shriveling, concentration of sugar and increase of berry's osmotic pressure that eventually kills the fungus (Rousseau and Donèche, 2001).

The fact that berries neighbor to infected ones can remain healthy when their skins are intact indicates that skin rupture is a necessary condition for botrytization (Pucheu-Planté and Seguin, 1978). The extent of berry's skin rupture is a decisive factor on whether the rot will turn to be gray or noble. In noble rot infection, berry's skin micro-fissures allow only $B$. cinerea to enter and germinate inside, leading to fungus growth in the interior of berry's skin where glycerol production in the anaerobic environment is supported (Pucheu-Planté and Seguin, 1978). According to Ribéreau-Gayon (1982), the origin of this very small ruptures that are invisible with naked eye can be skin tensions during berry's volume growth from veraison to maturity or stomata present on berries. On the other hand, intensive ruptures produced by birds, insects, worms, hail, light detachment of the berry from the pedicel or berry's skin bursting due to heavy rainfalls, lead to bunch rot. Extreme ruptures, make berries very susceptible to gray rot and lead to fungus growth at the exterior part of the berry, where oxidation of sugars leads to gluconic acid accumulation (Pucheu-Planté and Seguin, 1978).

The dominant Botrytis species (sp.) causing grape mold and ruining harvests is $B$. cinerea (sensu stricto alias Group II) (Fournier et al., 2013). This species along with $B$. cinerea Group I, also named as $B$. pseudocinerea, are living in sympatry on hosts such as grapevines (Walker et al., 2011). The latter has an insignificant effect on bunch rot development (Walker et al., 2011), while it is totally absent during noble rot infection (Fournier et al., 2013). Studies conducted in three different regions in France (Loire Valley, Bordeaux and Alsace) on B. cinerea infection, showed that only in Alsace there was a small differentiation of $B$. cinerea's genome compared to the other two regions. The fact that Alsace is geographically the most remoted region from the three, could explain this genetic diversity (Fournier et al., 2013). Concerning a comparison between gray and noble rot cultures found in the same vine plots, no differentiation of the genome of $B$. cinerea was found for the two types of infection for each of the three regions separately. This indicated that in each region the same fungus with the same genotype and probably same strains, were responsible for both bunch and noble rot (Fournier et al., 2013). What really changes between the two kinds of rots is the metabolic activity of the fungus in response to different environmental conditions. Microclimate is the most important factor promoting fungal development and secretion of metabolites beneficial or not for noble rot development (Fournier et al., 2013). Another study on cv. 'Semillon' grapes infected by noble rot highlighted that only $12 \%$ of the expressed genes were similar with those expressed in bunch rot. In other words, different transcription factors were upregulated during noble infection in the berry leading to different enzymatic production and metabolic paths (Blanco-Ulate et al., 2015).

It is well established for gray rot that the fungus uses more than 800 sRNAs during the infection, and 73 out of them are correlated with the defense mRNAs of the host cells (Weiberg et al., 2014). These mRNAs are responsible for the production of proteins, in ribosomes, able to act as shield against the parasite (Weiberg et al., 2014). Fungal sRNAs 
after penetrating in berry cells silence the defense mRNA by binding to Argonaute 1 (AGO1), a plant protein normally found in cells playing a role of stopping genes' expression whenever is needed by ceasing mRNAs' activity. A better understanding of this pattern occurrence during noble rot infection justifies further investigation (Weiberg et al., 2014).

\section{Vitis vinifera $L$. interaction with $B$. cinerea}

Environmental conditions are crucial for triggering different metabolic pathways during noble and gray rot infection. The up- or down-regulation of specific genes that decrease the power of the virulence factors secreted during noble rot colonization by $B$. cinerea, and result in a "milder" infection, is responsible for these metabolic differences (Lovato et al., 2019). Vitis vinifera L. also responses in a "gentler" way without activating all its defense mechanisms against the fungus as in gray mold case. The host decreases its defenses and produces lower number of phytoalexins responsible for the creation of hostile environment for the necrotrophic pathogen. Intense collision between host and parasite increases secreted compounds for both sides, leading to gray rot and decreasing grape quality (Lovato et al., 2019). The disruption of grape hormones by $B$. cinerea could explain the up- and down-regulation of specific genes during noble rot infection (Blanco-Ulate et al., 2015).

\section{BOTRYTIZATION PROCESS}

\section{Infection of the berry}

Wax presence around the skin $(2 \mu \mathrm{m})$ is the first line of berry's defense against infections, while berry's skin is the second (Ribéreau-Gayon et al., 2006a). The higher the berry's skin thickness, the higher the berry's resistance to microorganisms, and so the better the protection against $B$. cinerea. For example, 'Silvaner' $(100 \mu \mathrm{m})$ is less susceptible to gray rot than 'Müller-Thurgau' (50 $\mu \mathrm{m})$ (Ribéreau-Gayon et al., 2006a). Varieties used for noble rot wines such as 'Sauvignon Blanc' and 'Riesling' with approximately $175 \mu \mathrm{m}$ of skin thickness and 'Gewürztraminer' with around $250 \mu \mathrm{m}$, are rather resistant to gray mold before ripening. Their thick-skin berries make easier the sorting and picking during harvest (RibéreauGayon et al., 2006a).

Berry's skin is composed of cuticle, epidermis and hypodermis (König et al., 2017). The infection starts, when conidia from external sources colonize on mature berries via pre-existing micro-ruptures on cuticle not visible on the naked eye (Carrascosa et al., 2011). Under optimal microclimatic conditions their germination can start. B. cinerea uses cutinases against cuticle but whether or not it is possible to degrade it in order to reach the epidermis is still unknown. Yet, this happens during mycelia growth towards the exterior at pourri plein stage (Kamoen, 1992; Carrascosa et al., 2011; König et al., 2017).

As a necrotrophic organism, $B$. cinerea penetrates directly in the berries intracellular. It enters through berry's epidermis by producing high range of enzymes that induce cell wall degradation and cell death (Jackson, 2008). One of these enzymes is pectinase, which causes degradation of epidermal cells' pectic structures, liberating pectins and galacturonic acid later in the must (Pucheu-Planté and Mercier, 1983). Mycelium growth continuous inside the berry until reaches hypodermis level by the expansion of its filaments. Due to chitinases and $\beta$ glucanases presence in berry's pulp cells, enzymes that can break fungus cell wall and are considered as pathogenesis-related (PR) proteins, fungus will remain inside the berry at the skin surface (PucheuPlanté and Mercier, 1983).

At pourri plein stage of infection, $B$. cinerea starts its development towards the external part of grape skin. New conidiophores are dispersed by the wind over neighbor clusters in order to ensure new colonization. At this level of infection, oxidation phenomena are inevitable, so berries gain a characteristic brown color (Pucheu-Planté and Mercier, 1983). The results from the skin ruptures produced by the fungus are also related to high water evaporation and sugars concentration that lead to unbalanced change of osmotic pressure of the environment around the fungus that actually kills it. At the pourri rôti stage the withered grapes can be finally picked up (PucheuPlanté and Mercier, 1983).

\section{Induced botrytization}

The specific environmental conditions under which botrytization occurs, along with the effects of global warming in microclimates of wine regions, has aroused questions about a potential future incapacity of producing noble rot wines (Jackson, 2008). Studies were conducted in Italy, where noble rot occurrence is rather rare, regarding induced $B$. cinerea infection of red cv. 'Corvina' and 'Rondinella' and white cv. 'Garganega' (Fedrizzi et al., 2011; Tosi et al., 2012). Specifically, investigation on the effect of noble rot occurrence on traditionally produced 'Amarone' wines during a period of four months post-harvest grape drying, revealed that an artificial or not inoculation of $B$. cinerea could affect positively their organoleptic characteristics (Fedrizzi et al., 2011; Tosi et al., 2012).

The amelioration of the sensory characteristics of 
straw wines known as 'passito', after man-made inoculation during grapes withering, has also been argued by Lorenzini et al. (2012). Moreover, Negri et al. (2017) have demonstrated that post-harvest raisining followed by grapes' maintenance in humid chamber for natural $B$. cinerea infection have positively influenced the grapes' character compared to the non-infected ones. A comparison between a "Protected Designation of Origin" (PDO) noble rot wine and a wine produced by pre-harvest artificial botrytization of cv. 'Chardonnay' grapes, in terms of their aromatic profile, showed that typical aromas of noble rot wines were present in both wines (Wang et al., 2017). Odorant compounds naturally present in noble rot wines such as volatile thiols, lactones and furans were also detected on the artificial botrytized wine (Wang et al., 2017). Yet, whether or not a future pre- or post-harvest induced botrytization will be an acceptable technique to be implemented in PDO wine regions where traditionally noble rot wines are produced is still under discussion.

\section{ENVIRONMENTAL CONDITIONS}

\section{Optimum weather conditions for noble rot infection}

In general, production of very high-quality wines depends on many factors of equal importance such as microclimate, soil, viticulture and winemaking practices, vintage, among others (Pucheu-Planté and Seguin, 1981). For noble rot wine production, weather conditions are the key factor responsible for the quality of botrytization. Grapes should reach maturity healthy without skin ruptures to avoid bunch rot. The second step towards noble infection is $B$. cinerea presence on berries only under very specific sequential weather conditions (Pucheu-Planté and Seguin, 1981).

Taking Sauternes as an example, a region landmark for noble rot wine production, the average precipitation from January to July ranges from 500 to $600 \mathrm{~mm}$. Ideally, from the end of August to the end of September, the weather should be as dry as possible with maximum average rainfall between 30 to 40 $\mathrm{mm}$. Empirically, the first visual detection of $B$. cinerea is 15 to 20 days before berry's full ripeness, where the unfavorable environmental conditions make fungus growth very sluggish (Pucheu-Planté and Seguin, 1981). During October, consecutive rainy days of 60 to $70 \mathrm{~mm}$ of precipitation increase the level of humidity on berries, promoting germination of conidia and fungus exponential growth in less than ten days, and leading to berry-skin rupture towards the exterior. In a faultless way, after berry-skin rupture another ten sunny and dry days with humid nights and foggy mornings follow. Harvest start normally at the end of October when water losses and sugar concentration of berries achieve the desirable levels (Pucheu-Planté and Seguin, 1981).

In case that rain continues with insufficient number of sunny days, berries desiccation is impossible, while other undesirable fungus and bacteria develop. In case of insufficient amount of rain and humidity, $B$. cinerea development will be suppressed and the final wine will lose its distinctive character. The climate conditions of these three to five weeks after berry's ripeness are decisive for the quality of the final product (Pucheu-Planté and Seguin, 1981).

\section{Climate change}

Climate change, as one of the main topics discussed around the world, concerns every aspect of nature including human life. As a result, it arouses many queries and uncertainties also in wine industry (Bonnefoy et al., 2010). First and above all, climate change is very important in the viticulture part of wine production. Changes in phenological cycle of plants, changes in microclimate of regions in which terroir plays pivotal role on wine's organoleptic profile and increase of the possibility of annual severe weather phenomena, are only some of its effects (Bonnefoy et al., 2010). In regions where specific climatic conditions are very important for noble rot development on berries, climate change could disturb their microclimate leading to vintages either drier or more humid, affecting botrytization process (AgenisNevers, 2006). This explains why the discussion about artificial induction of $B$. cinerea, even in regions with tradition in this type of wine production, proceeds (Agenis-Nevers, 2006).

\section{VITICULTURE PRACTICES}

\section{Soil and rooting depth}

Gray rot depends on the abrupt increase of berry's volume due to intense water accumulation that leads to skin bursting. With extended ruptures, not only $B$. cinerea but any other microbial can colonize on berries, spoiling their qualitative characteristics (Pucheu-Planté and Seguin, 1978). In an area with same varieties, viticulture techniques and rootstocks, the problem of mold is always greater only in specific parcels where the vine roots are superficial and the soil is shallow. This observation, highlights the importance of soil depth and root system localization on potential gray mold infection (Pucheu-Planté and Seguin, 1978). 
The soil is one of the most important parameters regarding the degree of vine water stress. Considering Sauternes, where irrigation is not allowed, two types of soil exist (Pucheu-Planté and Seguin, 1981). The first type is mainly gravel and sandy, located at the upper part of small hills with a maximum altitude of $50 \mathrm{~m}$. This soil is rather homogenous and deep, with rooting depth up to five meters. The second type of soil consists mainly of clay beneath of a sallow sandy and silt layer of 50 to $60 \mathrm{~cm}$ depth that can cause water accumulation and roots asphyxia without a proper drainage system. In the first case, soil properties keep the vines during maturation under controlled water stress, ideal for grapes' ripening and aromatic enhancement (Pucheu-Planté and Seguin, 1981). Moreover, deep rooting leads to limited number of superficial roots, reducing water absorption and limiting berries' ruptures in case of intense precipitations during summer. Contradictory, vine's water uptake from shallow root system is easier due to increased water accumulation of the upper soil layers after heavy rainfalls (Pucheu-Planté and Seguin, 1978).

As the depth of the root system increases the percentage of gray mold decreases, starting from 100 cm with $70 \%$ occurrence of bunch rot up to $500 \mathrm{~cm}$ with only 5\% (Pucheu-Planté and Seguin, 1978). When berries are in the stage of late maturity and botrytization is the objective, the more intense the precipitation the higher the possibility of berry bursting in case of superficial rooting system. Deep soils with good drainage and potential rootstocks able to create deep rooting system are crucial for the production of botrytized wines of high quality (Pucheu-Planté and Seguin, 1978).

\section{Training system}

A study conducted over a period of four consecutive vintages on Sainte-Croix-du-Mont, a PDO region in Bordeaux, tried to identify differences between vines trained in two different trellis systems for the production of botrytized grapes and noble rot wines. Vertical shoot position (VSP) and Lyre were under examination, while the differences were based on sugar accumulation and aroma profile on wines (Carbonneau and Casteran, 1986). SP trellis system with $1.6 \mathrm{~m}$ vine distance between rows and trunk height at $40 \mathrm{~cm}$, VSP trellis system with $3.2 \mathrm{~m}$ vine distance between rows and trunk height at $70 \mathrm{~cm}$, and three types of Lyre training system (open, closed and truncated) with $3.2 \mathrm{~m}$ vine distance between rows and trunk height at $70 \mathrm{~cm}$, were examined. Vines with VSP trellis system and narrow distance $(1.6 \mathrm{~m})$, due to their sorter trunks height compared to the other cases, were infected and reached pourri plein and pourri rôti stages first. Vines with VSP trellis system and wide distance $(3.2 \mathrm{~m})$ were the last to be infected. The higher sugar content was detected in open Lyre samples and the lower was found in the sample from the VSP system with wide distance (Carbonneau and Casteran, 1986).

Tasting results on the aroma perception and intensity of the produced wines showed that the wines obtained from vines trained in open Lyre had the most complex and intense aromatic profile with the aromas of fruits, raisin and honey to be dominant (Carbonneau and Casteran, 1986). VSP samples with wide distances were ranked last in the tasting evaluation, having very a limited aromatic intensity and increased herbal aromas. The evaluation order from the best to the worst sample, according to the tasting panel, was: open Lyre, closed Lyre, truncated Lyre, narrow VSP and finally wide VSP (Carbonneau and Casteran, 1986). In total, Lyre system was the training system that produced the most qualitative results. It could be claimed that even if narrow plant density favored the infection at the beginning, at the end it was not an indispensable criterion for must and wine final quality. Although the VSP trellis system with narrow distance between rows and short trunk height produced qualitative wines, the Lyre training systems even with wide distances and long trunks were considered better. Manual harvest is the only option in respect to botrytized grapes both due to PDO regulations and sorting necessities. As a result, Lyre training system, in which mechanical pruning is also not possible, could replace training systems in VSP trellising, since their adaptability to mechanical pruning as one of their major advantages in this case is actually useless (Carbonneau and Casteran, 1986).

\section{METABOLIC DERIVATIVES OF BOTRYTIS CINEREA}

\section{Polysaccharides}

The two main polysaccharides secreted by $B$. cinerea have different solubilities in alcoholic solution (König et al., 2017). The first is a rather soluble heteropolysaccharide that consists of mannose $60 \%$, galactose $30 \%$, glucose $5 \%$, rhamnose $5 \%$ and a protein part (König et al., 2017). This heteropolysaccharide with molecular weight between $2.10^{4}$ and $5.10^{4} \mathrm{Da}$, known as botryticin, is a fungus antibiotic that acts toxically against plants (Dubourdieu et al., 1981). Concerning winemaking, it constrains yeast development leading to sluggish fermentation, and increased glycerol and acetate production (Dubourdieu et al., 1981). A homopolysaccharide called glucan or cinerean with 
limited solubility in alcoholic solution is the second main polysaccharide (König et al., 2017). Specifically, $\beta$-glucan with higher molecular weight between $10^{5}$ and $10^{6}$ Da consists of $\beta-1,3$ glucoses branched glycosidically $(\beta-1,6)$ with another glucose molecule (Dubourdieu et al., 1981).

B. cinerea's cell wall consists of glucans and chitin, which explains glucans abundance in botrytized grapes. The exterior part of this cell wall's molecule not only protect the fungus from vine's responses but also plays a linkage role with berry's skin at the first stage of fungus colonization (Dubourdieu et al., 1981). Harsh mechanical operations in the wine cellar, such as severe crushing and pumping, can increase the extraction of cinerean in the must, suppressing yeasts development and promoting glyceropyruvic fermentation. Later, in the wine, due to its limited solubility in alcohol, it is in suspension in the medium, producing clogging problems during filtration (Dubourdieu et al., 1981). Botryticin and $\beta$ glucans excreted by the fungus are estimated up to $750 \mathrm{mg} / \mathrm{L}$ in a ratio of 1:6 (Dubourdieu et al., 1981).

\section{Laccase}

Laccase is an enzyme that belongs to the polyphenol oxidase (PPO) enzyme group (Dubernet et al., 1977). Its enzymatic activity is optimal at temperatures around 30 to $40{ }^{\circ} \mathrm{C}$ and $\mathrm{pH} 4$ (Dubernet et al., 1977). This enzyme is responsible for oxidation of $O$ diphenols to semiquinones and subsequently to $o$ quinones. Caffeic and caftaric acids mainly, but also catechin and cyanidin, are the most important substrates of laccase (Dubernet et al., 1977). Other PPOs present in berries, such as tyrosinase, oxidize also monophenols, such as $p$-coumaric acid, or other than caftaric hydroxycinnamoyl tartaric acids, by converting them to $o$-diphenols via their cresolase activity. In all the cases, the produced $o$-quinones are responsible for the brown-dark color of oxidized white musts (Ribéreau-Gayon et al., 2006a).

Glutathione (GSH) is a tripeptide consisted of glutamic acid (Glu), cysteine (Cys) and glycine (Gly) that accumulates in berries during ripening (König et al., 2017). It is one of berry's responses to oxidative stress as it participates in detoxification pathways and reacts against toxic metals and peroxides (König et al., 2017). This compound is highly active with the produced o-quinones, forming 2-S-glutathionyl caftaric acid known as "Grape Reaction Product" (GRP) (Salgues et al., 1986). The formed compound is actually colorless preventing the enzymatic browning described above. Laccase is the only enzyme able to oxidize GRP by producing new $o$ quinones. These new compounds are combined in complex polymers contributing to the brown color of botrytized wines. GSH in surplus, is able to react with the produced $o$-quinones before their polymerization, producing another complex molecule with two GSH in its benzoic ring (alias GRP 2), not susceptible any more to laccase (Salgues et al., 1986). Due to extended phenolic oxidation and existence of laccase especially in botrytized must, addition of GSH for preventing browning is not useful (Salgues et al., 1986). B. cinerea secretes these enzymes as a response to berry's increased production of phenolic compound, that act as inhibitors of fungus growth (König et al., 2017).

In general, white varieties are less sensitive to laccase activity compared to the red ones (Boulton et al., 1999). Intensified coloring matter degradation, also known as "oxidasic casse", due to laccase severity, explains why noble rot wines are only produced from white varieties (Boulton et al., 1999). In infected berries, enzymatic activity is increased until pourri plein stage of infection (Table II). At pourri rôti stage of infection, $B$. cinerea's metabolic activity is gradually eliminated due to sugar concentration and increased osmotic pressure. Production of laccase is also decreased while its enzymatic activity falls below $40 \mu \mathrm{U}$ (Donèche, 1991). Sugar concentration of approximately $350 \mathrm{~g} / \mathrm{L}$ reduces oxygen saturation level in musts from $8 \mathrm{mg} / \mathrm{L}$ to less than $6 \mathrm{mg} / \mathrm{L}$, while oxygen consumption rate in botrytized musts is the same as in musts produced by healthy grapes (Donèche, 1991). This highlights the decrease of laccase activity in noble rot musts, yet the potential effects of this enzyme both in oxidation phenomena and color change should not be totally ignored during wine making. Therefore, hyperoxygenation technique in botrytized musts is not useful and thus not applicable (Donèche, 1991). Whether must heating treatment, with temperature at around $50{ }^{\circ} \mathrm{C}$ for laccase inactivation, is beneficial or not is still a debate. Unfavorable aroma modifications and losses are possible with this technique (König et al., 2017). Induction of selected $B$. cinerea's strains that produce lower amount of laccase could be another way to reduce their presence in grapes (König et al., 2017). In must, $125 \mathrm{mg} / \mathrm{L}$ of total sulfur dioxide $\left(\mathrm{SO}_{2}\right)$ is an adequate dose for laccase deactivation, while in wine total sulfur dioxide higher than $50 \mathrm{mg} / \mathrm{L}$ is sufficient (Jackson, 2008). 
Table II

Laccase activity during botrytization in berries (Donèche, 1991)

Actividade lacase em diferentes estádios da infecção do bago por Botrytis cinerea (Donèche, 1991)

\begin{tabular}{llcc}
\hline Stage of infection & $\begin{array}{c}\text { Sugar concentration } \\
(\mathbf{g} / \mathbf{L})\end{array}$ & $\begin{array}{c}\text { Laccase activity } \\
(\boldsymbol{\mu U} / \mathbf{b e r r y})\end{array}$ \\
\hline 1 & (healthy) & 218 & 0 \\
2 & & 220 & 9.4 \\
3 & & 223 & 57.8 \\
4 & (pourri plein) & 256 & 106.3 \\
5 & & 278 & 75.1 \\
6 & (pourri rôti) & 357 & 39.1 \\
\hline
\end{tabular}

\section{Proteases}

Nitrogen availability is very important for $B$. cinerea development on berries, given that it is a vital element for the production of amino acids, peptides and proteins that play fundamental role in metabolic activities of every living cell (Thakur, 2018). B. cinerea degrades berry's proteins, assimilates the nitrogen and produces new ones beneficial for each own survival. This degradation takes place catalytically under the presence of proteolytic enzymes produced by the fungus, increasing finally the levels both of fungal proteins and fungal proteases in the berries (Thakur, 2018). An increase of proteins up to $25 \%$, expressed in $\mathrm{g} / \mathrm{L}$ of botrytized musts compared to musts from uninfected grapes, depends exclusively on fungal proteins that are concentrated after berry's dehydration (Ribéreau-Gayon et al., 2006a).

PR proteins, such as thaumatin-like proteins (TLPs) and chitinases, even though are increased during infection are degraded by fungus proteases in berries and must (Girbau et al., 2004). A study conducted on healthy and botrytized berries and the corresponding musts, argued that PR proteins were always reduced during botrytization. According to the study, proteases' activity rather than berry's downregulation of genes for production of specific proteins is responsible for such a reduction (Girbau et al., 2004). As polar molecules, fungus proteolytic enzymes are also present in must, in which, due to their resistance in $\mathrm{pH}$, sulfur dioxide and heating, act against the remaining PR proteins (Marchal et al., 2006). The degradation of these proteins, that are considered the most difficult proteins to eliminate from wine, is beneficial for protein stabilization (Reynolds, 2010).

\section{BERRY'S CHEMICAL COMPOSITION}

Sugars and acids concentration on berry

During botrytization, berry's volume can decrease up to five times, intensifying concentration phenomena (Donèche, 1989). B. cinerea metabolizes sugars via Embden-Meyerhof pathway and hexose monophosphate shunt pathway (Donèche, 1989). Sugar decrease per berry, is up to $45 \%$ for 2.5 -fold berry's volume concentration after desiccation. Yet, this lost is not noticeable as berry's shriveling results in an average sugar content of $350 \mathrm{~g} / \mathrm{L}$ of must Table III (Donèche, 1989).

Reduction of tartaric and malic acid per berry is up to $85 \%$ and $45 \%$, respectively, again for 2.5 -fold berry's volume concentration after desiccation (RibéreauGayon, 1982). Tartaric acid decreases in $\mathrm{g} / \mathrm{L}$ of botrytized must by $55 \%$ and malic acid increases by $45 \%$. Thus, total acidity of around $8 \mathrm{~g} / \mathrm{L}$ expressed as tartaric acid is almost unchangeable, compared to musts derived from healthy grapes - Table III (Ribéreau-Gayon, 1982). Lesser acidity would result in flabby wines with cloying perception. Citric and acetic acid of botrytized must, both increase in $\mathrm{g} / \mathrm{L}$ by approximately $30 \%$ - Table III (Ribéreau-Gayon, 1982).

Finally, mucic acid, as another organic acid present naturally in grapes, can slightly increase after oxidation of galacturonic acid found in the must (Ribéreau-Gayon, 1982). The latter is abundant in botrytized musts after the extended enzymatic activity of pectinases during infection (Ribéreau-Gayon, 1982). Addition of commercial enzymes like polygalacturonases during pressing for better aromas extraction and more efficient settling during clarification is a treatment with limited effects, and therefore not recommended (Ribéreau-Gayon et al., 
2006a). The extended degradation of berry's pectic structure leads to the release of other sugars, such as arabinose, rhamnose, galactose, mannose and xylose, in the medium (Ribéreau-Gayon, 1982). As B. cinerea consumes mainly glucose, partial reduction of glucose concentration decreases the ratio between glucose and fructose below one, which can be used as indicator of infection (Garcia-Jares and Médina, 1997).

\section{Gluconic acid}

Gluconic acid and 2-keto gluconic acid are produced enzymatically by oxidation of the aldehyde functional group of glucose and the hydroxy functional group of $\mathrm{C}_{1}$ of fructose, respectively, under the presence of $B$. cinerea and oxygen (Donèche, 1989). In general, more than $0.5 \mathrm{~g} / \mathrm{L}$ of gluconic acid in must can be caused by bacteria or fungus contamination on berries (Moreno and Peinado, 2012). In berries infected by noble rot, gluconic acid concentration is above $3 \mathrm{~g} / \mathrm{L}$ and it is not metabolized by yeasts during alcoholic fermentation (Moreno and Peinado, 2012). Finally, it is considered as potential parameter for monitoring the degree of $B$. cinerea infection on berries (Cuadrado et al., 2005; Rolle et al., 2012; CarbajalIda et al., 2016).

\section{Polyalcohols}

There are three main polyalcohols responsible for the increased viscosity and the "body" of botrytized wines. Butanediol, glycerol or glycerin and sorbitol are present in infected grapes while the first two are also produced during alcoholic fermentation (Moreno and Peinado, 2012).

Table III

Berry's chemical composition expressed in per liter of must and per 1000 berries (Ribéreau-Gayon et al., 2006a)

Composição química do bago, por volume de mosto (L) e por número de bagos (1000) (Ribéreau-Gayon et al., 2006a)

\begin{tabular}{|c|c|c|c|c|}
\hline & \multicolumn{2}{|c|}{ Per liter } & \multicolumn{2}{|c|}{ Per berries } \\
\hline & $\begin{array}{c}\text { Healthy } \\
\text { must }\end{array}$ & $\begin{array}{c}\text { Botrytized } \\
\text { must }\end{array}$ & $\begin{array}{c}\text { Healthy } \\
\text { berry }\end{array}$ & $\begin{array}{c}\text { Botrytized } \\
\text { berry }\end{array}$ \\
\hline Weight (g) & & & 2020 & 980 \\
\hline Volume of must (mL) & & & 1190 & 450 \\
\hline $\mathrm{pH}$ & 3.33 & 3.62 & 3.33 & 3.62 \\
\hline Sugars (g) & 247 & 317 & 294 & 143 \\
\hline Glycerol (g) & Not detected & 7.4 & Not detected & 3.4 \\
\hline Total acidity ( $\mathrm{g}$ of tartaric acid) & 9.2 & 8.4 & 11 & 3.8 \\
\hline Tartaric acid (g) & 5.3 & 2.5 & 6.4 & 1.1 \\
\hline Malic acid (g) & 5.4 & 7.8 & 6.4 & 3.6 \\
\hline Citric acid (g) & 0.17 & 0.22 & 0.20 & 0.10 \\
\hline Acetic acid (g) & 0.32 & 0.41 & 0.38 & 0.14 \\
\hline Gluconic acid (g) & Not detected & 2.1 & Not detected & 0.94 \\
\hline Ammonium (mg) & 85 & 56 & 101 & 25 \\
\hline Proteins (mg) & 2815 & 3795 & 3350 & 1708 \\
\hline
\end{tabular}

Sorbitol concentration in berries does not exceed 600 $\mathrm{mg} / \mathrm{L}$, while 2,3-butanediol level is around $1 \mathrm{~g} / \mathrm{L}$ (Moreno and Peinado, 2012). Glycerol accumulation on berry is maximized at pourri plein stage under the lack of oxygen. Later it is oxidized to glyceraldehyde and decreases, reaching an average quantity of $5 \mathrm{~g} / \mathrm{L}$ in berries (Ribéreau-Gayon et al., 2006a). Moreover, it is the third most abundant component after water 
and ethanol in wines. Given that glycerol is also produced during fermentation, its concentration in botrytized wines can be higher than $20 \mathrm{~g} / \mathrm{L}$ (Moreno and Peinado, 2012). Glycerol along with gluconic acid are quality markers of $B$. cinerea infection (Ravji et al., 1988; Rolle et al., 2012; Tosi et al., 2012).

\section{Aroma precursors}

\section{Terpenes}

Mevalonic acid $\left(\mathrm{C}_{5}\right)$ is the key chemical compound for the production of terpenes (Blanco-Ulate et al., 2015). Experiments conducted on botrytized berries showed that it is present in higher quantities compared to health ones (Blanco-Ulate et al., 2015). This means that via the mevalonate pathway (MVP) and the methylerythritol-4-phosphate pathway (MEP), production of the main terpenoid precursors dimethylallyl pyrophosphate (DMAPP) and isopentyl pyrophosphate (IPP) take place. From these precursors a variety of aromatic compounds such as monoterpenoids $\left(\mathrm{C}_{10}\right)$ and sesquiterpenoids $\left(\mathrm{C}_{15}\right)$ can be present in the wine directly. While others, such as $\mathrm{C}_{13}$-norisoprenoids, can be present indirectly after enzymatic or oxidative cleavage of Carotenoids $\left(\mathrm{C}_{40}\right)$ (Blanco-Ulate et al., 2015).

These odorant compounds, which are considered as primary wine aromas and are found in berries in their glycosylated forms, seems to be oxidized after the aglycone part is being liberated catalytically under the presence of $B$. cinerea's glycosidases (RibéreauGayon et al., 2006a). The process involves an $\omega$ hydroxylation reaction in which a hydrogen from the terminal methyl of a terpene such as geraniol, is substituted for a hydroxyl group ( $\omega$-oxidation), converting geraniol to a less odorant diol while the wine loses its varietal character (Bock et al., 1988). This explains the use of varieties such as 'Semillon' or 'Chenin Blanc' less depended on their aromatic character during botrytized wine production. 'Muscat' grapes, for example, diminished their aromatic profile rather than gain in complexity after botrytization (Jackson, 2008). Addition of glycosidases during or after alcoholic fermentation for enhancing the aromatic profile of botrytized wines is not recommended (Jackson, 2008).

\section{Thiol precursors}

Degradation of fatty acids to $\mathrm{C}_{6}$ compounds (alcohols and aldehydes with six carbons) normally occurs in healthy grapes (Blanco-Ulate et al., 2015). The process during berry ripening starts from breakdown of unsaturated fatty acids within the lipoxygenase (LOX) cycle, which is catalyzed enzymatically and produces hydroperoxides (Blanco-Ulate et al., 2015). These are also enzymatically degraded to $\mathrm{C}_{6}$ compounds such as (E)-2-hexenal known as leaf aldehyde and (Z)-3-hexen-1-ol known as leaf alcohol. $\mathrm{GSH}$, whose the production increases during noble rot infection, is combined by glutathione $S$-transferases (GSTs) with $\mathrm{C}_{6}$ compounds during detoxification pathways, creating $S$-glutathione conjugates that are actually thiol precursors. The expression of the genes responsible for GSTs formation are also upregulated during botrytization (Blanco-Ulate et al., 2015). A sequential conversion of $S$-glutathione precursors leads to $S$-cysteinylated precursors by elimination of Glu and Gly from the molecule. A final cleavage from $\beta$-lyases during alcoholic fermentation liberates thiols in wine matrix, which is vital for the aroma enhancement (Blanco-Ulate et al., 2015).

Quinones (oxidized polyphenols) are highly reactive with volatile thiols (Quideau et al., 1995). In botrytized wines, polyphenols are almost eliminated by oxidization, polymerization and precipitation phenomena under the enzymatic activity of laccase (Quideau et al., 1995). $\mathrm{C}_{6}$ compounds are considered pre-fermentative aromas, derived from unsaturated fatty acids (such as linoleic and linolenic acids), being released in the must during maceration, destemming, crushing and pressing. The cleavage of linoleic and linolenic acids during pre-fermentation processes follows the same LOX pathway described above (Ferreira et al., 1995).

Other higher alcohols present in these wines, such as 1-octen-3-ol (known for its mushroom distinctive aroma), derive from fatty acids degradation, during metabolic pathways of other microorganism such as bacteria present on berries during botrytization (Jackson, 2008).

A study conducted on cv. 'Semillon' and 'Sauvignon Blanc' grapes at every stage of botrytization process from healthy ripe to late pourri rôti berries, indicated that concentration of cysteinylated precursor of 3mercapto-1-hexanol $(3 \mathrm{MH})$ for both varieties was around 100 times higher than the control until the stage of pourri plein (Thibon et al., 2009). A later decrease of this compound in berries due to oxidation or combustion was not highly noticeable in $\mathrm{mg} / \mathrm{L}$ due to parallel water evaporation. The same study tried to compare the differences between overripe sound grapes at late harvest and botrytized ones regarding the quantities of the Cys3 $\mathrm{MH}$ in order to highlight the pivotal role of $B$. cinerea infection and how it affects directly or not berry's metabolic pathways (Thibon et al., 2009). Indeed, an average ten times increase of this compound for both varieties during botrytization was ascribed to the previous argue. The diastereoisomeric ratio between $\mathrm{R} / \mathrm{S}$ Cys $3 \mathrm{MH}$ forms was actually the same between on and off-vine 
botrytization and overripening and equal to 30:70. This expresses an indirect involvement of $B$. cinerea in $3 \mathrm{MH}$ production (Thibon et al., 2009). Again, as above-mentioned $S$-glutathione precursors and the enzymes involved in berries seem to be two crucial steps for the release of these very aromatic thiols later in wine (Thibon et al., 2009).

\section{Benzaldehyde}

Benzyl alcohol is an aromatic higher alcohol normally absent from healthy grapes and dry wines (Swiegers et al., 2005). It is produced by berries during $B$. cinerea infection as it is a limiting factor in fungus development (Goetghebeur et al., 1993). B. cinerea acts against this compound enzymatically, by producing benzyl alcohol oxidase that converts benzyl alcohol to benzaldehyde (Goetghebeur et al., 1993). The latter is only found in noble rot wines, in which its bitter almond aroma enchases their aromatic profile (Bailly et al., 2006; Fedrizzi et al., 2011; Negri et al., 2017).

\section{Phenylpropanoid pathway}

The phenylpropanoid pathway is one of the most important metabolic paths of red grape varieties (Chen et al., 2006). Via this pathway, berry produces many secondary derivatives mainly located in the skin, such as phenolic acids, stilbenes, anthocyanins, flavanols and flavonols (Chen et al., 2006). These compounds are the response of berries to the increased vine stress caused by biotic and abiotic factors, and play a vital role in the organoleptic characteristics of the final product (Chen et al., 2006). Phenylpropanoid metabolic activity is marginal in white grape varieties except when they are infected by $B$. cinerea (Blanco-Ulate et al., 2015). When infection takes place in white berries, their response derives from the upregulation of specific transcription factors followed by the expression of specific genes for the production of enzymes that will induce, among others, this metabolic path during berries' maturation (Blanco-Ulate et al., 2015).

\section{Phenolic acids and hydroxycinnamic esters}

In the early stages of phenylpropanoid pathway during botrytization, increased production and accumulation of the three main hydroxycinnamic acids, $p$-coumaric, caffeic and ferulic in berries, is noticeable (Blanco-Ulate et al., 2015). Yet, PPOs such as laccase and tyrosinase oxidize these acids along with their hydroxycinnamic esters such as caftaric and coutaric acids (Dubernet et al., 1977). Accordingly, a study on cv. 'Chenin Blanc' from Loire Valley region during botrytization highlighted the oxidation of these esters during infection (Carbajal-Ida et al., 2016).

\section{Stilbenes}

Stilbenes are 1.2-diphenylethylene derivatives very important non-flavonoid compounds widespread in nature (Hart, 1981). They act as phytoalexins produced by plants in response to microbial or insect colonization (Hart, 1981). Resveratrol is one of the most well-known and studied stilbenes in wine industry due to its beneficial properties in human health (Frankel et al., 1993). Specifically, transresveratrol seems to act as antioxidant, preventing the oxidation of low-density lipoprotein that is correlated with heart diseases (Frankel et al., 1993). It is also considered as cancer-preventative substance that can deter or constrain tumor development (Jang et al., 1997). Production of stilbenes is generally increased in botrytized grapes (Blanco-Ulate et al., 2015).

$B$. cinerea seems to be very little affected by resveratrol's presence in berries. It dimerizes resveratrol oxidatively to inactivate products potentially under the enzymatic activity of laccase (Cichewicz et al., 2000). A study carried out in Sauternes region concerning botrytized grapes highlighted that resveratrol increased as infection expanded in berries from cv. 'Semillon', while in 'Sauvignon Blanc' the opposite behavior was observed (Landrault et al., 2002). In both varieties the quantity of trans-resveratrol was lower than 0.15 $\mathrm{mg} / \mathrm{kg}$ of grapes. Other stilbenes found in these grapes, such as trans-astringin, trans-piceid and pallidol, were also present in very limited concentrations. Only $\varepsilon$-viniferin, a resveratrol dimer, was an exception following an increasing trend in both varieties up to $2 \mathrm{mg} / \mathrm{kg}$ of grapes before infection reached pourri plein stage, while after was reduced to half (Landrault et al., 2002).

\section{Other phenolic compounds}

Numerous phenolic compounds that are highly produced during infection, acting against $B$. cinerea and as antioxidants, are also relevant from the oenological point of view regarding the enhancement of the unique flavor of this kind of wines (BlancoUlate et al., 2015). Flavonols such as quercetin and kaempferol in their glycosylated forms are eliminated from berries at the last stage of infection, while myricetin is identified only in pourri rôti phase (Carbajal-Ida et al., 2016). Flavanols such as catechin, epicatechin and galloyl epicatechin also increase during botrytization, reaching a maximum at the final stage of infection; according to Goetz et al. (1999) they act against fungus' enzymes, and more specifically against stilbene oxidases.

In total, for the cv. 'Chenin Blanc', the phenolic composition decreased up to $40 \%$ throughout noble 
rot infection (Carbajal-Ida et al., 2016). Even though berry activates every possible defense mechanism against $B$. cinerea, fungus finally prevails by degrading enzymatically most of the produced phenolic compounds (Ribéreau-Gayon et al., 2006b). Phenolic composition, excluding tyrosol, is noticeably lower in botrytized wines compared to dry ones - Table IV (Ribéreau-Gayon et al., 2006b). Tyrosol as yeasts' by-product remains in the wine matrix after alcoholic fermentation, constituting $40 \%$ of the total phenolic compounds and having a strong honey wax reminiscence that contributes to the honey-like characteristic aromatic category of these wines (Jackson, 2008).

Table IV

Phenolic content of dry and botrytized wine (Ribéreau-Gayon et al., 2006b)

Composição fenólica de um vinho branco seco e de um vinho botritizado (Ribéreau-Gayon et al., 2006b)

\begin{tabular}{|c|c|c|c|c|}
\hline & \multicolumn{2}{|c|}{ Dry white wine } & \multicolumn{2}{|c|}{ Noble rot wine } \\
\hline & Content (mg/L) & $\%$ & Content (mg/L) & $\%$ \\
\hline Tyrosol & 25 & 22.2 & 29 & 40.5 \\
\hline Gallic acid & 1.4 & 1.2 & 1.0 & 1.4 \\
\hline Caffeic acid & 13.5 & 12 & 0.2 & 0.3 \\
\hline$p$-Coumaric acid & 2.6 & 2.3 & & \\
\hline Quercetin & 0.2 & 0.2 & & \\
\hline Tannins (procyanidins) & 70 & 62.1 & 41.3 & 57.7 \\
\hline Total phenolic compounds & 112.7 & 100 & 71.5 & 100 \\
\hline
\end{tabular}

\section{Quality markers}

The exponential phase of $B$. cinerea development is carried out in the internal part of berry's skin, where deprivation of oxygen results to fungus incapacity of glucose assimilation (Donèche, 1989). Nicotinamide adenine dinucleotide (NAD) is a cofactor playing pivotal role in microorganisms' metabolic activities. Reduction of dihydroxyacetone phosphate (DHAP) to glycerol-3-phosphate is carried out enzymatically by glycerol-3-phosphate dehydrogenase (Donèche, 1989). This process guarantees fungus metabolic activity and survival, and leads to glycerol accumulation in berries (Donèche, 1989). As $B$. cinerea begins to grow at the external part of berry's skin at the stationary phase of its development, gluconic acid starts accumulating in berries due to glucose oxidation by glucose oxidase (GOx) (Ribéreau-Gayon et al., 2006a). The duration of $B$. cinerea presence in internal and external part of grape skin, determines the concentration of glycerol and gluconic acid, respectively. Optimal environmental conditions lead to rapid berry shriveling, reducing the period of fungus occurrence externally and limiting gluconic acid accumulation on berries (RibéreauGayon et al., 2006a). The ratio between glycerol and gluconic acid is considered as noble rot quality index, the higher the ratio the higher the quality of the potential wine (Ribéreau-Gayon et al., 2006a).

\section{BERRY'S MICROBIOLOGY}

\section{Other fungus}

During noble rot infection, colonization of other molds on berry skin is always possible under the condition that $B$. cinerea is the dominant fungus (Pucheu-Planté and Seguin, 1978). Contrary to bunch rot, in noble rot infection populations of other microorganisms on grapes are 10.000 times less compared to B. cinerea (Pucheu-Planté and Seguin, 1978). The most common saprophytes on noble rot berries are Penicillium expansum, Penicillium crustosum, Aspergillus niger and Alternaria alternata (Lorenzini et al., 2012). Experimentation on intended co-inoculation of different pairs of these molds with $B$. cinerea on grapes showed the different metabolic pathways of each one and how they affected berry's composition (Lorenzini et al., 2012). B. cinerea along with Penicillium and Aspergillus spp. affected the level of shriveling due to increased water losses. These fungi promoted the oxidation of glycose to gluconic acid catalyzed by GOx. High amount of gluconic acid reduced the quality of infected grapes (Lorenzini et al., 2012). In general, even if absolute 
fungus monoculture infection is rather rare, the higher the purity of $B$. cinerea colonization on grapes the higher the quality of the final product (Lorenzini et al., 2012).

\section{Bacteria}

A study conducted in Sauternes revealed that Gluconobacter spp., and especially Gluconobacter oxydans, are present on berries during botrytization. Comparison of these bacteria's CFU with healthy musts highlighted the importance of the infection and its severity in berries' microbial load (Barbe et al., 2001). Acetic acid bacteria are by far the most dominant bacteria found on berries during noble rot Table V (Barbe et al., 2001). The three main compounds responsible for the high sulfur dioxide binding capacity of botrytized musts are gluconic acid, 5-oxofructose and dihydroxyacetone (DHA). According to Barbe et al. (2001), Gluconobacter oxydans present in botrytized grapes is directly correlated with the accumulation of these compounds produced by the oxidation of glucose, fructose and glycerol, respectively. Acetobacter aceti and Acetobacter pasteurianus dominated progressively noble rot musts during fermentation conducted at 21 ${ }^{\circ} \mathrm{C}$ in wood barrels. Acetobacter aceti is responsible for acetic acid production also during maturation in barrels, especially when $\mathrm{pH}$ and temperature are high (Joyeux et al., 1984).

Table V

Presence of acetic acid bacteria in botrytized must for three consecutive vintages (Barbe et al., 2001)

Presença de bactérias acéticas em mostos de uvas botritizadas em três vindimas consecutivas (Barbe et al., 2001)

\begin{tabular}{|c|c|c|c|c|}
\hline \multirow{2}{*}{ Harvest } & \multirow{2}{*}{ Samples } & \multicolumn{3}{|c|}{ Acetic bacteria / Total bacteria } \\
\hline & & Minimum & Average & Maximum \\
\hline 1995 & 24 & $0 \%$ & $69 \%$ & $100 \%$ \\
\hline 1996 & 46 & $41 \%$ & $95 \%$ & $100 \%$ \\
\hline 1997 & 12 & $62 \%$ & $94 \%$ & $100 \%$ \\
\hline
\end{tabular}

\section{FROM GRAPE TO MUST}

\section{Harvest}

Due to high heterogeneity of berries' shriveling degree during infection, the presence of more than one variety for noble rot wine production is beneficial (Pucheu-Planté and Mercier, 1983). Sorting three to four times each harvest period, selectively hand picking of clusters or part of them at pourri rôti stage, is mandatory to ensure homogeneity and thus typicity of produced wines (Pucheu-Planté and Mercier, 1983). For this reason, the harvest for noble rot wines cannot be done mechanically (Thakur, 2018). The choice of the perfect harvest date is crucial for the production of this type of wines. In addition to berry's shriveling degree, harvest is based on botrytization process that promotes an intense enzymatic maceration of the grape skin, similar to red skin maceration in vats. The longer and deeper this process is in berries, the greater the release of varietal aromas such as thiols precursors in must (RibéreauGayon et al., 2006a). Compared to botrytized wines, the aromatic profile of straw wines is less complex. While berries are drying under the sun, their varietal aromas undergo thermal cleavage, reducing the aromatic potentials of the final product (RibéreauGayon et al., 2006a).

\section{Markers for evaluating the infection and proposing harvest date}

Standardization of the evaluation of $B$. cinerea's infection on berries is crucial for noble rot wine production. The establishment of the optimum harvest date based on objective factors allows reducing human error (Lorenzini et al., 2015; Carbajal-Ida et al., 2016). Thus far, validation of fungus growth stage is based on the personal experience of winemakers while human eye is the main verification tool (Lorenzini et al., 2015; Carbajal-Ida et al., 2016). Puncture and compression tests are potential markers found in the literature for evaluating the infection (Carbajal-Ida et al., 2016). Both are based on the principle that the higher the degree of infection the more extended the skin degradation by fungus's enzymes. In the puncture test, a sensor penetrates on the berry until the skin is ruptured, while in the compression test two parallel plates press the berry until its deformation reaches $70 \%$. Both tests measure the required forces for achieving the targets, the lower 
the applied force the more advanced the stage of infection (Carbajal-Ida et al., 2016). Berry's myricetin levels is another proposal for evaluating botrytization as it is a phenolic compound normally absent from grapes (Carbajal-Ida et al., 2016). It has been found only in berries at pourri rôti stage of infection probably produced by berries as response to parasite's presence (Carbajal-Ida et al., 2016). Finally, the amount of proteins in berries is another evaluation test based on the principle that $B$. cinerea causes enzymatic degradation of proteins (Lorenzini et al., 2015). The lower the amount of berries' proteins the higher the botrytization. Further evaluation of these procedures is required, namely in terms of time consuming, reliability of the results and applicability during the very stressful period of harvest (Lorenzini et al., 2015).

\section{Cryoextraction technique}

As harvest takes place manually and botrytization degree is firstly evaluated subjectively by the winemaker and then by the harvesters during hand picking, the method of cryoextraction seems very efficient (Reynolds, 2010). The principle of this technique derives from icewine production and it is based on the high sugar content of infected grapes by B. cinerea at pourri rôti stage (Reynolds, 2010). The higher the amount of sugars the lower the freezing temperature of berries. The harvested grapes are transferred in freezing chambers where temperature range from $0^{\circ} \mathrm{C}$ to $-16{ }^{\circ} \mathrm{C}$ (Ribéreau-Gayon et al., 2006a). The produced must derives only from grapes highly botrytized with high sugar content and more qualitative and full-bodied juice (Ribéreau-Gayon et al., 2006a). The extractability of aromatic compounds from skin increase due to intense skin burns by frost (Ribéreau-Gayon et al., 2006a). This technique can also be applied during harvests of below average vintages, when lack of sunny days do not allow sufficient berry desiccation leading to berry's water excess and dilution of sugar content (Ribéreau-Gayon et al., 2006a).

\section{Pressing}

A sorting table is recommended to be used after harvest for separating part of clusters that are less or not infected or co-infected by other fungus and bacteria (Thakur, 2018). In some cases, crushing without destemming, in which stems facilitate pressing and their extracted tannins facilitate protein stabilization, with subsequent maceration for sugar and aromas extraction in inert gas atmosphere are followed by pressings (Jackson, 2008). Direct pressing without crushing and maceration is another option that can be followed and depends on winemaker decision (Jackson, 2008). In general, the main principle for this type of wine production is to avoid the release of particles such as glucans in the must (Jackson, 2008). These colloids will produce later clarification problems and will hamper the stabilization processes. Thus, minimization of frictions by using gravity during berries' transfer and decrease of harshness of every operation, such as pumpings, are vital (Jackson, 2008). Continuous presses increase liberation of undesirable particles in the must, while pneumatic ones provide with inadequate pressing, up to 2 bars maximum (Ribéreau-Gayon et al., 2006a). Both types are not recommended for noble rot grapes. Yet, pneumatic pressing is a sustainable choice for cryoextraction technique (Ribéreau-Gayon et al., 2006a). Movinghead presses are the best option as they can apply pressure on grapes up to 12 bars. The most qualitative juice with the higher sugar content is obtained by the last pressing cycles (Ribéreau-Gayon et al., 2006a).

\section{Settling before fermentation}

The high sugar concentration and the existence of colloidal particles in the must, make settling rather difficult (Ribéreau-Gayon et al., 2006a). Yet, settling at temperatures lower than $10^{\circ} \mathrm{C}$ for 28 to 48 hours is beneficial. As lees is a source of fatty acids, sterols, among others, which are important for yeast development, excessive clarification increases the possibility of stuck or sluggish fermentation (Ribéreau-Gayon et al., 2006a). The optimum turbidity, without facing problems of bitter, reductive and herbaceous notes is in-between 500 and 600 NTU (Ribéreau-Gayon et al., 2006a). Addition of lees, saved from settling of previously produced dry white wine, in tank or barrel filled with botrytized must, is a boosting factor for yeasts development during fermentation (Ribéreau-Gayon et al., 2006a).

\section{IONS CONTENT OF BOTRYTIZED MUST}

\section{Anions}

Phosphates and sulfates are the anions with the highest concentrations in must and wine (Moreno and Peinado, 2012). Phosphates are naturally present in grapes, while their normal levels in white wines are between 75 and $500 \mathrm{mg} / \mathrm{L}$. This fluctuation depends on the use or not of diammonium phosphates as source of yeasts' assimilable nitrogen (Moreno and Peinado, 2012). Origins of sulfates are endogenous since their presence in grapes varies from 0.1 to 0.4 $\mathrm{g} / \mathrm{L}$ expressed as potassium sulfate or exogenous deriving from viticulture treatments with copper sulfate against downy mildew (Moreno and Peinado, 2012). During winemaking, other possible sources are the addition of yeast nutrients like ammonium sulfate 
and copper sulfate treatment against reductive notes (Moreno and Peinado, 2012). Yet, the most important origin of sulfates for botrytized wines is sulfur dioxide addition. Oxidation of sulfur dioxide, during barrel aging, leads to sulfate accumulation (Moreno and Peinado, 2012). Normal levels of sulfates found in other types of wines are between 0.15-0.7 g/L expressed as potassium sulfate, while for this specific category they can reach even $2 \mathrm{~g} / \mathrm{L}$ (Moreno and Peinado, 2012).

\section{Cations}

Potassium is the main cation present in wines and is responsible for tartaric instability (Moreno and Peinado, 2012). In botrytized and straw wines, it is highly increased up to $2 \mathrm{~g} / \mathrm{L}$, due to concentration effect of berry's shriveling (Moreno and Peinado, 2012). Calcium is also a source of instability mainly due to tartrate precipitation under the form of calcium bitartrate. It is considered the most difficult tartaric instability to control, as precipitation mainly occurs during storage (Jackson, 2008). Calcium concentration is increased up to $140 \mathrm{mg} / \mathrm{L}$ in noble rot wines, leading to formation of other salts except of tartaric, such as gluconic and mucic whose concentrations are also increased for this type of wines (Jackson, 2008).

\section{GLYCEROPYRUVIC AND ALCOHOLIC FERMENTATION}

\section{Glyceropyruvic fermentation}

Synthesis of glycerol in must from healthy grapes, with sugar content around $240 \mathrm{~g} / \mathrm{L}$, starts before alcoholic fermentation (Moreno and Peinado, 2012). Glyceropyruvic fermentation takes place providing the wine with an average concentration of 5 to $10 \mathrm{~g} / \mathrm{L}$ of glycerol (Moreno and Peinado, 2012). In botrytized wines, concentration of glycerol is increased with an average of $16 \mathrm{~g} / \mathrm{L}$, partly due to the extended glyceropyruvic fermentation (MorenoArribas and Polo, 2009). More in detail, normally during alcoholic fermentation ethanol production by the reduction of ethanal is carried out since yeast needs to re-oxidize $\mathrm{NADH}_{2}$, the reduced form of NAD, back to $\mathrm{NAD}^{+}$in order to continue its metabolic activity. Limited amount of ethanal at the beginning of fermentation, parallel to its strong affinity with sulfur dioxide in sulfited musts like botrytized ones, block this step (Moreno-Arribas and Polo, 2009).

Alternative to ethanal, yeast uses dihydroxyacetone (DHA) that is reduced to glycerol, increasing consequently the concentration of the latter in the must (Moreno-Arribas and Polo, 2009). Glycerol is very important not only for yeasts' high osmolarity and redox equilibrium but also for improvement of organoleptic characteristics of wine (Moreno-Arribas and Polo, 2009). Glycolysis still takes place during glyceropyruvic fermentation since breakdown of fermentative sugars up to $8 \%$, leads to pyruvic acid accumulation and then to secondary products such as ethanal and acetate. This explains why, as it happens with glycerol, the major portion of volatile acidity (VA) is generated during yeasts' growth phase (Bely et al., 2003). Glycerol content is independent of the maximum yeasts' population, the produced VA and the assimilable nitrogen present in must (Bely et al., 2003). When sulfur dioxide decreases and ethanal is in sufficient amount, alcoholic fermentation and so ethanol production start (Bely et al., 2003).

\section{Alcoholic fermentation kinetics}

It is well known that "stuck" fermentation can be caused by many factors that affect and finally inhibit yeasts' metabolic activities (Bisson, 1999). During spontaneous fermentation one of these factors can be the problematic multiplication of Saccharomyces cerevisiae under hostile environment, as other yeasts species and microorganisms are present on must, making difficult its colonization and establishment in the medium (Bisson, 1999).

Following a spontaneous alcoholic fermentation of noble rot must with a sugar content of $320 \mathrm{~g} / \mathrm{L}$ showed that after yeasts' growth phase, fermentation rate stayed stable and maximum during stationary phase, until the $11^{\text {th }}$ day of fermentation when death phase started (Lafon-Lafourcade and RibéreauGayon, 1979). At this moment the average daily degradation of sugars fell from $15 \mathrm{~g} / \mathrm{L}$ to $5 \mathrm{~g} / \mathrm{L}$. At the $15^{\text {th }}$ day from the beginning of fermentation, $170 \mathrm{~g} / \mathrm{L}$ of sugar had been already metabolized. During death phase the number of living yeasts decreased rapidly and sugar consumption felt at $35 \mathrm{~g} / \mathrm{L}$ in 24 days. Fermentation stopped after 40 days, with a level of residual sugars at $100 \mathrm{~g} / \mathrm{L}$ (Lafon-Lafourcade and Ribéreau-Gayon, 1979). The extremely high sugar content of these wines affected yeasts' growth phase due to the hyperosmotic environment that eventually led to "stuck" fermentation. An experiment conducted in musts from sound grapes and different sugar contents, revealed this trend (Lafon-Lafourcade and Ribéreau-Gayon, 1979).

Different blends of two types of musts, one coming from botrytized grapes with sugar content of $420 \mathrm{~g} / \mathrm{L}$ and one from healthy grapes with content of $220 \mathrm{~g} / \mathrm{L}$, all corrected at the same sugar level with sucrose addition, showed different fermentation rates (LafonLafourcade and Ribéreau-Gayon, 1979). The lower 
fermentation rate derived from the blend with the higher ratio of botrytized must indicated that specific compounds present on botrytized must act as inhibitors against yeasts' development (LafonLafourcade and Ribéreau-Gayon, 1979). Isolation and addition of botryticin in noble rot musts showed increased production both of glycerol and acetic acid, highlighting its activity against yeasts' growth (Ribéreau-Gayon et al., 2006a).

Fermentation kinetics of free-run and pressed botrytized must from different pressings, showed that the must from the last pressing caused the most sluggish fermentation (Lafon-Lafourcade and Ribéreau-Gayon, 1979). Compounds with $B$. cinerea's origin, such as $\beta$-glucans, also act as yeasts' inhibitors. Their release in must is correlated with the harshness of wine making techniques (LafonLafourcade and Ribéreau-Gayon, 1979). Finally, one other very important inhibitory factor for yeasts was also the lack of assimilable nitrogen, which was metabolized almost totally by the fungus (LafonLafourcade and Ribéreau-Gayon, 1979). Addition of nutrients at the beginning of fermentation assured sufficient yeasts multiplication, increasing fermentation rate during stationary phase (LafonLafourcade and Ribéreau-Gayon, 1979). In order to ensure that after stopping fermentation residual sugars would be less than $90 \mathrm{~g} / \mathrm{L}$, inoculation of specific yeast strains that can survive for longer time under all these unfavored conditions with parallel addition of nutrients are obligatory (Lafon-Lafourcade and Ribéreau-Gayon, 1979).

\section{Assimilable nitrogen correction in must}

After harvesting botrytized grapes and during alcoholic fermentation, high concentration of sugars up to $400 \mathrm{~g} / \mathrm{L}$ along with limited assimilable nitrogen content can cause stuck fermentation and increase the VA from 1.1 to $1.6 \mathrm{~g} / \mathrm{L}$ expressed as acetic acid (Bely et al., 2003). In noble rot musts, VA produced by yeasts without bacteria participation can exceed the legal limits for white wines, 20 milliequivalents per liter or $1.20 \mathrm{~g} / \mathrm{L}$ expressed as acetic acid (OIV, 2020), reaching a final content of more than $2.0 \mathrm{~g} / \mathrm{L}$ (Bely et $a l ., 2003)$. In contrast to the average nitrogen content of $180 \mathrm{mg} / \mathrm{L}$ for bordelaise dry white musts, the average available nitrogen in noble rot grapes was estimated at around $84 \mathrm{mg} / \mathrm{L}$ with a worth mentioned minimum of even $25 \mathrm{mg} / \mathrm{L}$ (Bely et al., 2003). A study conducted during the fermentation of the obtained musts with and without addition of ammonium salts, showed that increase of nitrogen content generated an increase on yeasts population that subsequently resulted to decreased VA production (Bely et al., 2003).
Accumulation of $80 \%$ of the total VA in the samples took place during yeasts' growth phase. More than that, VA decreased up to $40 \%$ when must of $350 \mathrm{~g} / \mathrm{L}$ of sugars reached $210 \mathrm{mg} / \mathrm{L}$ of assimilable nitrogen compared to the same must with content at around $100 \mathrm{mg} / \mathrm{L}$ (Bely et al., 2003). Nevertheless, addition of nitrogen more than $210 \mathrm{mg} / \mathrm{L}$ resulted to increased yeasts bioactivity that led to acetate overproduction. The best time for nitrogen addition in the must was at the beginning of fermentation, at a density of around $1140 \mathrm{~g} / \mathrm{L}$ and definitely before yeasts reached the stationary phase, two to three days after yeasts' inoculation (1100 g/L) (Bely et al., 2003). Finally, a correction on must assimilable nitrogen up to 190 $\mathrm{mg} / \mathrm{L}$ was proposed as the optimum concentration for a must with sugar content of $350 \mathrm{~g} / \mathrm{L}$ (Bely et al., 2003). All the above-mentioned highlight the importance of measuring the assimilable nitrogen in pre-fermented sweet musts and make the corrections without being based on general estimations, in order to avoid sluggish fermentation and high production of VA (Bely et al., 2003).

\section{Thiamine addition}

Thiamine or Vitamin $B_{1}$, as part of the enzyme carboxylase is very important for its production (Ribéreau-Gayon et al., 2006a). It is an enzyme excreted by yeasts that removes the carboxylic groups from ketonic acids during fermentation. Pyruvic acid for example is converted to ethanal and later to ethanol. Thus, thiamine plays important role in yeasts metabolism by decreasing acetate production and VA (Ribéreau-Gayon et al., 2006a). For botrytized musts, thiamine is vital for diminishing carbonyl compounds, like pyruvic and $\alpha$-ketoglutaric acid, which are counting for $20 \%$ and $16 \%$ of sulfur dioxide binding, respectively, by promoting their decarboxylation (Ribéreau-Gayon et al., 2006a). In botrytized musts in which fermentation takes place under unfavorable conditions, production of these acids especially at the beginning is much higher than in white musts from sound grapes. Addition of thiamine in botrytized musts can decrease in average the bounded sulfur dioxide by $20 \mathrm{mg} / \mathrm{L}$ (RibéreauGayon et al., 2006a). The depravation of this vitamin in berries and later in must is actually induced by $B$. cinerea (Thakur, 2018). Addition of sulfites in must inactivates even more the already feeble amount of this vitamin (Jackson, 2008). Addition of $50 \mathrm{mg} / \mathrm{L}$ of vitamin $\mathrm{B}_{1}$, along with other nutrients parallel to yeast inoculation in clarified must, is the best way to assure higher sulfur dioxide efficiency due to limited accumulation of pyruvic and $\alpha$-ketoglutaric acid and limited binding (Ribéreau-Gayon et al., 2006a). The maximum amount of thiamine hydrochloride addition 
in must is $60 \mathrm{mg} / \mathrm{hL}$ expressed as thiamine (EEC, 2009).

\section{Vat types for fermentation}

Two types of containers can be used during fermentation, stainless-steel tank or wooden barrel (Ribéreau-Gayon et al., 2006a). When fermentation takes place in barrel, wood pores allow oxygen dissolution in must that favors yeasts' activity, producing wines with less residual sugars and higher ethanol content. Temperature during fermentation in barrel ranges from $12{ }^{\circ} \mathrm{C}$ in Tokaj to $28{ }^{\circ} \mathrm{C}$ in Sauternes (Magyar, 2011). Temperature control at around $20{ }^{\circ} \mathrm{C}$ to $24{ }^{\circ} \mathrm{C}$ is much easier in stainlesssteel tanks, favoring yeasts' fermentation rate (Ribéreau-Gayon et al., 2006a). When fermentation takes place in stainless-steel tank, the contact of juice with oxygen is preferable after yeasts' growth phase, for beneficial ALF and reduced VA (Ribéreau-Gayon et al., 2006a). It is advisable to conduct fermentation, regardless of the type of fermenter, in small volume containers for separating different batches of grapes that derive from sortings during harvest. In this way, these batches keep separately their unique character, gained during botrytization, facilitating blending at the end (Jackson, 2008).

\section{Yeast species during fermentation}

\section{Candida spp.}

A study conducted on botrytized musts, tried to investigate the adaptation capacity and the evolution of yeast species during spontaneous fermentation at two different temperatures $\left(20^{\circ} \mathrm{C}\right.$ and $\left.30^{\circ} \mathrm{C}\right)$ with $\mathrm{pH}$ 3.57 (Mills et al., 2002). Only Candida and Klyveromyces spp. persist during the $30{ }^{\circ} \mathrm{C}$ fermentation, while all the other species were actually eliminated in the early stages. An explanation could be the incapacity of non-Saccharomyces spp. adaptation under the very fast ethanol accumulation (Mills et al., 2002). The durability of all the species at $20{ }^{\circ} \mathrm{C}$ was higher. During the $30{ }^{\circ} \mathrm{C}$ fermentation, the presence of Candida spp. was reduced sharply as soon as alcohol content reached $6 \%$ vol, while in the other case the population was not reduced until $12.5 \%$ vol of alcohol was achieved. Candida spp. were very important even in cases of dry yeast inoculated musts , with noticeable presence in the medium during fermentation (Mills et al., 2002).

Investigation on benefits of Candida stellata on aroma profile of dry wines was carried out, revealing an amelioration on the analytical profile of wines after successive inoculation of Candida stellata and Saccharomyces cerevisiae during fermentation (Ciani and Ferraro, 1998), and an intensification of aromas of stone fruits and honey after monoculture fermentation with this Candida sp. (Soden et al., 2000). Bibliography also mentions an increase of glycerol production under the presence of Candida stellata parallel to a very low fermentation rate, while the trend of acetate production is quite controversial (Ciani and Ferraro, 1996; Ciani et al., 2000; Soden et al., 2000).

According to Sipiczki (2004), previously published articles concerning Candida stellata sp. most probably referred to Candida zemplinina sp. A research carried out on high sugar must fermentation after simultaneous inoculation of Candida zemplinina (syn Starmerella bacillaris) and Saccharomyces cerevisiae compared to monoculture fermentation of the latter, demonstrated $0.3 \mathrm{~g} / \mathrm{L}$ lower VA expressed as acetic acid and sufficient ethanol and glycerol production (Rantsiou et al., 2012). On the contrary, a fermentation after subsequent inoculation was sluggish in terms of alcohol accumulation while VA was $50 \%$ reduced, indicating the limited impact of high sugar content as yeasts' inhibitor during fermentation when other yeasts species are present (Rantsiou et al., 2012). The fructophilic character of Candida stellata changes the ratio of glucose/fructose and helps Saccharomyces cerevisiae with sluggish problems. The role of Candida stellata or Candida zemplinina in co-inoculated, sequential inoculated or non-inoculated fermentation and their impact on wine's organoleptic characteristics, need further research before strong conclusions can be drawn (Magyar and Tóth, 2011).

\section{Torulaspora delbrueckii}

Finally, another study tried to investigate the potentials of Torulaspora delbrueckii, another yeast species known for limited levels of VA accumulation in fermentative musts (Bely et al., 2008). Measurements after alcoholic fermentation of botrytized musts, with sugar content of $360 \mathrm{~g} / \mathrm{L}$, verified the above statement regarding VA, even though ethanol accumulation did not reach desired levels since the fermentation was actually sluggish. Co-inoculation with Saccharomyces cerevisiae provided wines with low VA and ethanal concentration meaning reduced binding capacity with sulfur dioxide. Subsequent inoculation again with Saccharomyces cerevisiae incorporation after five days was unsuccessful regarding the same two parameters (Bely et al., 2008). Simultaneous inoculation of both the two species with ratio $20: 1$ in favor of Torulaspora delbrueckii provided the best results when compared to monoculture Saccharomyces cerevisiae fermentation, again in terms of VA and ethanal, with $53 \%$ and $60 \%$ decrease respectively (Bely et al., 2008). 


\section{"Mutage" operation}

The antimicrobial properties of sulfur dioxide can be used for delaying the beginning of alcoholic fermentation or in higher doses even finishing it (Ribéreau-Gayon et al., 2006a). Only molecular sulfur is active against Saccharomyces cerevisiae because it is the only form that can pass through the cell wall into the cytoplasm of the yeast where it dissociates due to the high $\mathrm{pH}$ 6-7 and kills the yeast from the interior by reacting with vital compounds and unbalancing the redox equilibrium (RibéreauGayon et al., 2006a). "Mutage", refers to an operation where addition of at least $100 \mathrm{mg} / \mathrm{L}$ of sulfur dioxide can cease fermentation (Sudraud and Chauvet, 1985). According to some studies, the safest dose for stopping fermentation is $1.50 \mathrm{mg} / \mathrm{L}$ of molecular or active sulfur. For assuring a good conservation of these wines without any refermentation problems after racking and aging, 1.20 $\mathrm{mg} / \mathrm{L}$ of active sulfur is sufficient (Sudraud and Chauvet, 1985).

"Mutage" is carried out when sugar and alcohol levels are at a desired equilibrium, providing well balanced wines without excess alcohol or cloying perception (Ribéreau-Gayon et al., 2006a). Empirically, the ratio of 13:3, 14:4 and 15:5 between the actual and potential alcohol strength is a potential guide to follow, but it is rather rare to achieve it when fermentation stops spontaneously. In most cases, "mutage" is applied when fermentation rate is very low, increasing VA without actually reducing sugars, or in the opposite case where sugar degradation is very extensive. The balance and the equilibrium in these wines is ensured during blending, in which different batches can be mixed (Ribéreau-Gayon et al., 2006a). A common practice nowadays before adding sulfur dioxide is the decrease of wine temperature at $-4{ }^{\circ} \mathrm{C}$ followed by centrifugation or racking in order to eliminate a high amount of yeasts. This will ensure a more effective treatment. The amount of total sulfur dioxide added to the must, in order to achieve around $50 \mathrm{mg} / \mathrm{L}$ of free, is between 200 and 300 mg/L (Ribéreau-Gayon et al., 2006a).

\section{SULFUR DIOXIDE}

\section{Binding capacity and antioxidant properties in} botrytized musts and wines

Alcoholic fermentation of botrytized wines stops by "mutage". As previously mentioned, the proper dose of sulfur dioxide for avoiding refermentation problems ranges between 200 and $300 \mathrm{mg} / \mathrm{L}$. This dosage is higher than the sulfur dioxide addition in dry red or white wines, because botrytization increases the number of sulfur dioxide binding compounds in must, and finally in wine (Barbe et al., 2000). These compounds are partially produced by $B$. cinerea and bacteria present in infected grapes. Yet, most of the molecules with the strongest affinity with sulfur dioxide derive either from alcoholic fermentation or oxidation of sugars (Barbe et al., 2000).

An experiment conducted on different musts and wines from Sauternes, tried to identify specific compounds that combine sulfur dioxide, thus increasing the amount of sulfur dioxide required to stabilize it. (Barbe et al., 2000). According to the results, the three main substances with the stronger binding affinity identified in musts were carbonyl compounds. More specifically, these compounds were $\gamma$ - and $\delta$-gluconolactone, both in chemical equilibrium with gluconic acid (only $10 \%$ was in acid's form), 5-oxofructose with an average content of $100 \mathrm{mg} / \mathrm{L}$ that was bound with $60 \%$ of the total sulfur dioxide and DHA. The latter, was in equilibrium with glyceraldehyde, explaining its very limited presence in must. DHA was metabolized by yeasts during alcoholic fermentation, while the other two were still present in wine accounting for $50 \%$ of the total binging capacity of sulfur dioxide. These compounds along with the following yeasts' derivatives (produced during ALF) - ethanal, pyruvic acid and 2-oxoglutaric acid - were considered responsible for binding with sulfur dioxide and increasing its addition in botrytized wines (Barbe et al., 2000).

Different amounts of the three alcoholic fermentation by-products identified in different wines were correlated with different yeast strains (Masneuf and Dubourdieu, 2000). A study conducted in different musts, one fermented spontaneously by indigenous yeasts and three inoculated with different industrial dry yeast strains, intended to correlate the production of these compounds during fermentation with their binding capacity, for a aimed concentration of 50 $\mathrm{mg} / \mathrm{L}$ of free sulfur dioxide after "mutage" (Masneuf and Dubourdieu, 2000). The wine from spontaneous fermentation had the second lower binding capacity with sulfur dioxide, while the wine from Saccharomyces cerevisiae $\mathrm{BO} 213$ fermentation, a strain highly appreciated in Sauternes region for the production of noble rot wines, needed the highest amount of total sulfur dioxide addition $(336 \mathrm{mg} / \mathrm{L})$. This strain produced in average $55 \mathrm{mg} / \mathrm{L}$ of ethanal, corresponding to approximately $82 \mathrm{mg}$ of bound sulfur dioxide, $117 \mathrm{mg} / \mathrm{L}$ of pyruvic acid, and 130 $\mathrm{mg} / \mathrm{L}$ of 2-oxoglutaric acid. Indigenous yeasts naturally present in botrytized must had the best adaptation in such a medium with so many 
fermentation inhibitors (Masneuf and Dubourdieu, 2000).

Ethanal compared to other compounds has the strongest affinity with sulfur dioxide (Barbe et al., 2000). In wines derived from already sulfited musts, a common practice applied in many wineries, ethanal's levels are higher than in wines from non-sulfited ones (Barbe et al., 2000). Sulfur dioxide blocks yeast's metabolic pathways, leading to an increased ethanal accumulation as response (Barbe et al., 2000). Empirically, it is known that approximately only half of sulfur dioxide added in the must is actually bound with compounds For this reason, the usual winemaking strategy of adding 30 to $50 \mathrm{mg} / \mathrm{L}$ of sulfur dioxide in must, to avoid fermentation, microbial spoilages and laccase activity, is actually beneficial (Ribéreau-Gayon et al., 2006a). Botrytized must composition and wine matrix varies from vintage to vintage according to the intensity of infection. Although an average of 200 to $300 \mathrm{mg} / \mathrm{L}$ of total sulfur dioxide can be added to reach the targeted $50 \mathrm{mg} / \mathrm{L}$ of free sulfur dioxide, there is no general rule on the ratio between combined and free sulfur dioxide. For all the above-mentioned reasons the maximum acceptable limits of total sulfur dioxide for these wines is $400 \mathrm{mg} / \mathrm{L}$ (EEC, 2009).

Sulfur dioxide not only suppresses the enzymatic activity of laccase but also reacts with the produced $o$-quinones, that are highly oxidative, by reducing them back to $o$-diphenols (Waterhouse et al., 2016). Sulfur dioxide acts against hydrogen peroxide, a powerful oxidant produced by the oxidation of $o$ diphenols to semiquinones and then to $o$-quinones via the hypothetical mechanism: hydroperoxyl radical step (Waterhouse et al., 2016). Without sulfur dioxide presence in must and wine, hydrogen peroxide is decomposed to a hydroxyl radical under the catalytic presence of iron, able to oxidize a large number of compounds, known as the "Fenton reaction". This explains the limited binding capacity of sulfur dioxide against oxygen. In fact, sulfur dioxide reaction with oxygen is rather slower in botrytized musts than in healthy musts (Waterhouse et al., 2016).

\section{AROMATIC COMPOUNDS IN NOBLE ROT WINES}

\section{Lactones}

Lactones can be cyclic carboxylic esters of gamma $(\gamma)$ and delta $(\delta)$ hydroxy-acids easily formed under mildly acidic environment after the cleavage of fatty acids during berry's LOX pathway, a process known as "lactonization" (Moreno and Peinado, 2012). The produced $\gamma$-nonalactone, $\gamma$-decalactone and $\delta$ decalactone (Figure 2) with distinct aromas of apricot and peach have been identified in Sauternes wines (Sarrazin et al., 2007a). In Australian botrytized wines, $\gamma$-nonalactone and $\gamma$-octalactone (coconut aroma) were identified in the highest concentrations 59 and $8.5 \mu \mathrm{g} / \mathrm{L}$, respectively, compared to a total of 58 white wines (Cooke et al., 2009). Both of them were above their threshold limits, which are 25 and 7 $\mu \mathrm{g} / \mathrm{L}$, respectively (Waterhouse et al., 2016). Moreover, $\gamma$-3-methyloctalactone, known as whisky lactone, that is a tertiary aroma compound with coconut flavor extracted from wood during barrel aging, was also present in aged Sauternes wines (Sarrazin et al., 2007a).

2-Furanone derivatives are other type of lactones, which are found both in botrytized berries and young Aszú wines from Tokaj region, enhancing their aromatic profile with stone fruit notes (Miklósy et al., 2004; Miklósy and Kerényi, 2004). Even though 2furanone or $\gamma$-crotonolactone is a lactone, its origin differs from the previously mentioned lactonization pathway. 2-Furanone, with caramel aroma, results from the oxidation of furfural, which is proposed to be previously formed by hydrolysis of $\mathrm{C}_{5}$ sugar oligomers and subsequent dehydration of the produced monomer (Serrano-Ruiz et al., 2012), or it is a Maillard reaction's product (Banerjee et al., 1981).

HPLC analysis of botrytized wines revealed the presence of 2-nonen-4-olide, among other compounds characteristic of these wines (Stamatopoulos et al., 2015). This compound is a 2-furanone type lactone, which has the second lowest perception threshold $(10.8 \mu \mathrm{g} / \mathrm{L})$ after whisky lactone, and is mainly associated with fruity and minty aromas only found in this type of wines. This compound along with whisky lactone, eugenol and $\gamma$-nonalactone seem to be responsible for the creation of the synthetic aroma of candied orange (Figure 2), highlighting the importance of lactones in wine matrix not only individually but also synergistically especially after barrel aging (Stamatopoulos et al., 2015).

\section{Sotolon}

3-Hydroxy-4,5-dimethilfuran-2(5H)-one, widely known as sotolon, is a compound landmark for Port aged wines with sensory character of curry, fenugreek, nuts and dried fruits, and a threshold of 19 $\mu \mathrm{g} / \mathrm{L}$ (Ferreira et al., 2003). 


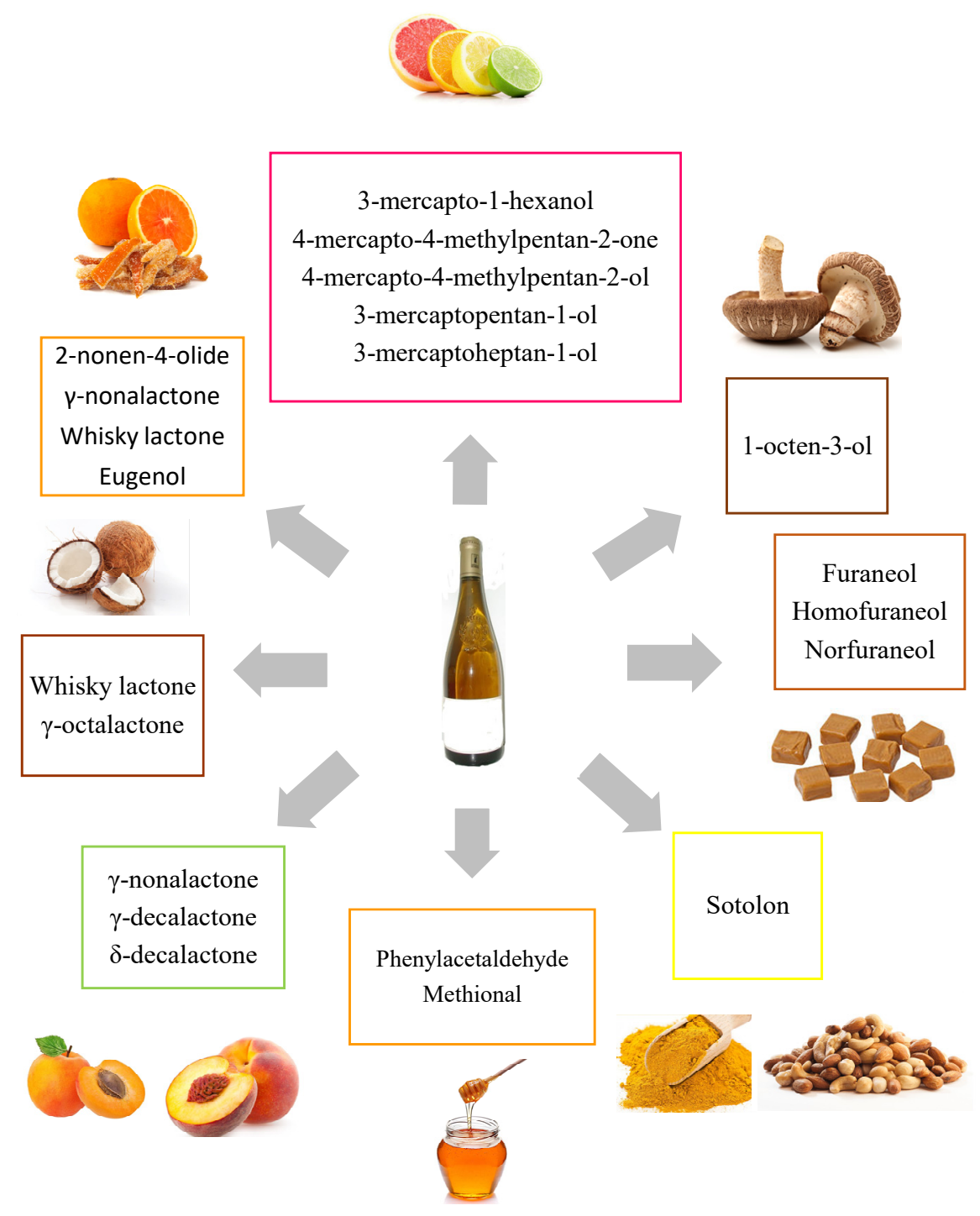

Figure 2. Basic odorant compounds within the main four aromatic groups found in botrytized wines.

Compostos odorantes dos principais grupos de compostos do aroma encontrados nos vinhos botritizados.

Its accumulation was found to be induced under oxidative conditions and although its production pathway is not yet completely clarified, the involvement of glycolaldehyde and diacetyl, which are both by-products of Maillard reaction, was proposed (Ferreira et al., 2003). Even though sotolon is considered as lactone and more precisely as 2furanone derivative, it is preferable to be mentioned separately since it is identified in Sauternes wines Figure 2 (Sarrazin et al., 2007a).
The impacts of botrytization on grapes, such as oxidation and sugar concentration, seem to create the perfect substate for sotolon production after aging (Sarrazin et al., 2007a). According to Masuda et al. (1984), 5 to $20 \mu \mathrm{g} / \mathrm{L}$ were present in these wines compared to a maximum of $1 \mu \mathrm{g} / \mathrm{L}$ in the dry ones, while its threshold limit for these sweet wines was around $5 \mu \mathrm{g} / \mathrm{L}$. On the contrary, seminar studies from Hungary on Aszú wines from Tokaj, indicated a nonsignificant identification of sotolon on young wine 
matrices (Tóth-Markus et al., 2002; Miklósy et al., 2004). However, before strong conclusions can be drawn further studies on aged Aszú wines are recommended.

\section{Thiols}

3-Mercaptohexan-1-ol (3MH) is the most important thiol in botrytized wines (Table VI). It has been identified in concentrations of $5000 \mathrm{ng} / \mathrm{L}$ after years of storage (perception threshold of $50 \mathrm{ng} / \mathrm{L}$ ), enhancing the aroma profile of wine with notes of citrus peel, grapefruit and passion fruit (Bailly et al., 2006; Tominaga et al., 2006; Sarrazin et al., 2007a; Thibon et al., 2009; Blanco-Ulate et al., 2015). Other thiols have been identified to act synergistically with each other improving the final aromatic profile of the wine (Sarrazin et al., 2007b). Indicatively, 4mercapto-4-methylpentan-2-one, 4-mercapto-4methylpentan-2-ol, 3-mercaptopentan-1-ol and 3mercaptoheptan-1-ol (Figure 2) are responsible for aromas of citrus fruits (Sarrazin et al., 2007b).

Table VI

Concentration of 3MH for wines obtained by grapes in different stages of infection (Sarrazin et al., 2007b)

Concentração de $3 \mathrm{MH}$ em vinhos obtidos a partir de uvas em diferentes estádios de infecção (Sarrazin et al., 2007b)

\begin{tabular}{|c|c|c|c|c|}
\hline Variety & Botrytization stage & $\begin{array}{c}\text { Mean grape } \\
\text { volume } \\
(\mathrm{mL})\end{array}$ & $\begin{array}{c}\text { Variation of mean } \\
\text { grape volume } \\
(\%)\end{array}$ & $\begin{array}{l}3 \mathrm{MH} \\
(\mathrm{ng} / \mathrm{L})\end{array}$ \\
\hline \multirow{4}{*}{ 'Semillon' } & Healthy & 0.85 & 100 & 195 \\
\hline & Pourri plein & 0.68 & 80 & 2326 \\
\hline & Pourri rôti & 0.37 & 44 & 3678 \\
\hline & Late pourri rôti & 0.38 & 45 & 6334 \\
\hline \multirow{4}{*}{ 'Sauvignon Blanc' } & Healthy & 0.78 & 100 & 161 \\
\hline & Pourri plein & 0.52 & 67 & 3003 \\
\hline & Pourri rôti & 0.21 & 27 & 9648 \\
\hline & Late pourri rôti & 0.29 & 37 & 9319 \\
\hline
\end{tabular}

Multidimensional gas chromatography-mass spectrometry-olfactometry (MDGC-MS-O) analysis of young Sauternes wines indicated for the first time the existence of 3-propyl-1,2-oxathiolane, which is not a volatile thiol but has similar odor of citrus fruits (Sarrazin et al., 2010). It has never been identified in white dry wines, and its origin is proposed to be 3,3'dithiobis(1-hexanol), a $3 \mathrm{MH}$ disulfide, that is cleaved to 3-propyl-1,2-oxathiolane and 3MH after thermal degradation. The potential mechanism for the production of 3,3'-dithiobis(1-hexanol) at the first place involves $S-S$ conjugation of two 3sulfanylhexan-1-ol molecules in oxidative environment without polyphenols presence in the medium (Sarrazin et al., 2010).

Polyphenols in botrytized wines have almost been eliminated by oxidization, polymerization and precipitation phenomena under the enzymatic activity of laccase, so they are actually inactive otherwise, after being oxidized to quinones would be highly reactive against volatile thiols including $3 \mathrm{MH}$ (Quideau et al., 1995). Therefore, 3-propyl-1,2oxathiolane cannot be present in dry white wines (Sarrazin et al., 2010). Absence of it in noble rot wines during barrel aging under the presence of oxygen reinforced the hypothesis of $3 \mathrm{MH}$ dimer presence in wine (Sarrazin et al., 2010). Identification of this compound will lend further support to this theory, and will allow a better understanding on thiols behavior during bottle aging and conservation in domestic conditions (Sarrazin et al., 2010).

\section{Phenylacetaldehyde}

Other very important odorant compounds in botrytized wines are the previously mentioned benzaldehyde and furfural, with almond-like aromas, 
and phenylacetaldehyde, with aroma of honey Figure 2 (Kikuchi et al., 1983). In the past, these compounds were erroneously considered as $B$. cinerea metabolites (Kikuchi et al., 1983). Phenylacetaldehyde was mentioned in recent studies as a compound identified in high concentration in botrytized wines, whose origin is strongly correlated with the fungus and the oxidative environment it creates on berries (Sarrazin et al., 2007a). Its concentration increased during infection, while it was not found in sound grapes and musts.

A study showed that even though phenylacetaldehyde had a strong affinity with sulfur dioxide, its concentration was increased during fermentation (Sarrazin et al., 2007a). A potential mechanism, where phenylpyruvic acid as precursor (produced enzymatically during botrytization) was converted by yeasts to phenylacetaldehyde during fermentation, was proposed. Finally, it was found that this aldehyde decreased during aging without being totally eliminated (Sarrazin et al., 2007a).

\section{Furaneol and derivatives}

Furaneol, homofuraneol and norfuraneol contribute with their caramel-like notes to the aroma profile of noble rot wines since their concentration exceed the perception threshold - Figure 2 (Sarrazin et al., 2007a). These three compounds have very limited affinity with sulfur dioxide due to their complex structure. Given that they were not identified in musts from both botrytized and healthy grapes but only in corresponding wines, they were considered to be present in increased concentrations in botrytized wines due to the shriveling effect of $B$. cinerea on the berry and not directly due to the infection (Sarrazin et al., 2007a). In fact, water evaporation from berries during infection concentrates all the compounds, including the ones responsible for the aromas.

\section{Higher alcohols and esters}

Higher alcohols, which are alcohols with more than two carbon atoms on their molecule, are compounds produced by yeasts during ALF, mainly during amino acids degradation via a mechanism known as "Ehrlich reaction" (Reynolds, 2010). More specifically, 2phenylethanol along with its ester, phenylethyl acetate, both with notes of rose, are very specific aromatic compounds identified in botrytized wines (Tóth-Markus et al., 2002; Bailly et al., 2009; Fedrizzi et al., 2011; Tosi et al., 2012). Another remarkable higher alcohol found in botrytized wines is methionol, with aroma of cooked potato (Sarrazin et al., 2007a; Fedrizzi et al., 2011; Tosi et al., 2012). This higher alcohol is oxidized to methional during barrel aging of botrytized wines, which explains the increasing of methional over the time (Sarrazin et al., 2007a). Although methional is not directly linked with honey-like aroma, it was identified in honey and it is considered that together with phenylacetaldehyde it contributes to wine's aromatic profile (Sarrazin et al., 2007a). Finally, ethyl hexanoate is an ester associated with the characteristic aroma of green apple, formed during fermentation by condensation of fatty acids and acetyl coenzyme A without participation of higher alcohols (Swiegers et al., 2005). It is found in botrytized wines even after aging in bottle (Sarrazin et al., 2007a; Bailly et al., 2009).

\section{Sensory evaluation}

A comparative evaluation on the distinctive aroma profile of three types of sweet wines produced after botrytization, raisining, and fortification was conducted by experts in wine tasting under the method of citation frequency (González-Álvarez et al., 2014). According to the results, citrus fruits, stone fruits, floral and animal aromas where dominant in botrytized wines. Between seven more specific characteristics, the differentiation of botrytized wines from the other two was much clearer. Aromas such as muscat, grapefruit, bay leaf and mushroom were much more intense than in the other two wine categories. Straw and fortified wines showed many similarities among them compared to noble rot wines.(González-Álvarez et al., 2014). Evaluation by professionals on the typicity of noble rot wines at a regional scale showed that the majority of bordelaise wines from Sauternes, Barsac and Loupiac were differentiated compared to other French sweet wines produced by botrytization or raisining (Sarrazin, 2008).

\section{STABILIZATION AND AGING}

\section{Microbiological stabilization}

\section{Refermentation problems}

Zygosaccharomyces bailii, Sacharomycodes ludwigii and strains of Saccharomyces cerevisiae are very durable in the unfavored environment of botrytized wine matrix (Ribéreau-Gayon et al., 2006a). These yeasts species are responsible for refermentation during barrel aging or bottling. A potential refermentation can easily start when temperature is higher than $15^{\circ} \mathrm{C}$ and wine stays in contact with lees. (Ribéreau-Gayon et al., 2006a). Cold treatment followed by "mutage" and clarification by racking, not only decrease the amount of sulfur dioxide that needs to be added to stop fermentation but also stabilize the wine in terms of potential future refermentations (Figure 3) (Ribéreau-Gayon et al., 2006a). 


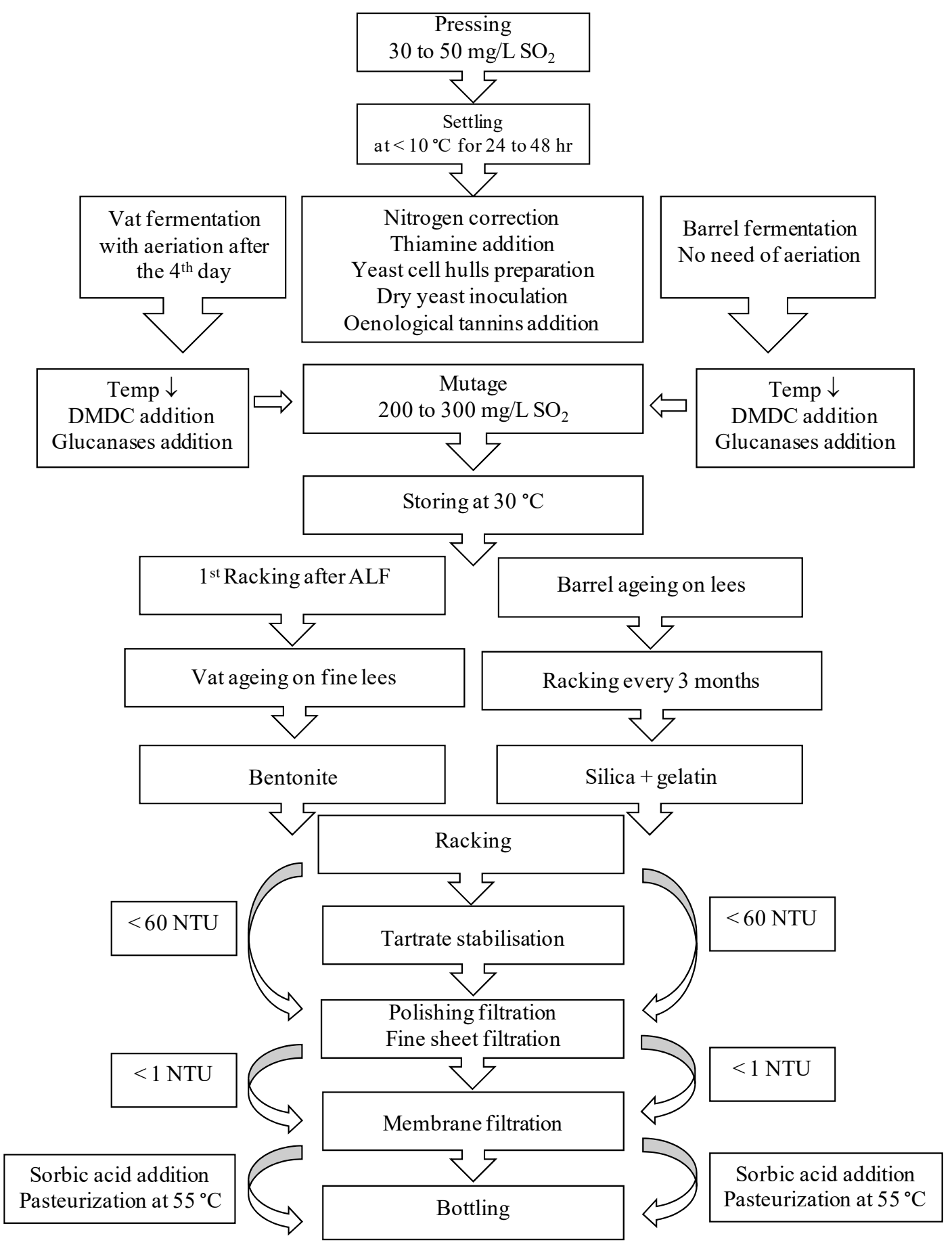

Figure 3. Winemaking diagram for fermentation and aging of botrytized wines in barrel and vat.

Diagrama de vinificação e envelhecimento de vinhos botritizados em barrica e em cuba. 


\section{Pasteurization}

Due to the increased amount of both free and combined sulfur dioxide, the ratio in favor of free can change by increasing temporary the storage temperature from $15{ }^{\circ} \mathrm{C}$ to $30{ }^{\circ} \mathrm{C}$ right after "mutage" (Ribéreau-Gayon et al., 2006a). Depending on the conditions, this can liberate up to $20 \mathrm{mg} / \mathrm{L}$ of combined sulfur dioxide, while the equilibrium between free and combined sulfur dioxide changes in favor of the first. The effect of mild heating not exceeding $50-55^{\circ} \mathrm{C}$ for seven to ten minutes can be used to avoid potential refermentation during aging - Figure 3 (Ribéreau-Gayon et al., 2006a). If this process is followed in regular intervals, when yeasts populations exceeds 1000 cells $/ \mathrm{mL}$, and just before bottling, the final product can be microbiologically stable. In this case, a significantly lower targeted amount of free sulfur dioxide, at around $30 \mathrm{mg} / \mathrm{L}$, protects the wine. This contributes to a reduction in the total amount of sulfur dioxide of more than $60 \mathrm{mg} / \mathrm{L}$ (Ribéreau-Gayon et al., 2006a).

\section{Sorbic acid}

Sorbic acid is added to the wine just before bottling to avoid refermentation during storage - Figure 3 (Ribéreau-Gayon et al., 2006a). It is an additive complementary to sulfur dioxide that acts against yeasts. It inhibits yeast growth without affecting bacteria or avoiding oxidation but it cannot be used for ceasing fermentation during "mutage", (RibéreauGayon et al., 2006a). The addition of sorbic acid during bottling can decrease the recommended dose of free sulfur dioxide only from 50 to $40 \mathrm{mg} / \mathrm{L}$ depending on the alcoholic strength and $\mathrm{pH}$ of wine (Ribéreau-Gayon et al., 2006a). The maximum acceptable dose of sorbic acid is $200 \mathrm{mg} / \mathrm{L}$, expressed as potassium sorbate, due to its high insolubility to water (EEC, 2019).

\section{Dimethyl dicarbonate}

Dimethyl dicarbonate (DMDC) is an additive that acts against yeasts, and it is recommended to be used during bottling (Divol et al., 2005). In the case of noble rot wines, it can be also used during "mutage" to decrease sulfur dioxide addition (Figure 3). DMDC cannot replace sulfur dioxide as antioxidant and antiseptic but it can cease more effectively ALF in healthy musts (Divol et al., 2005). Besides, for the complex matrix of botrytized musts DMDC should always be used along with sulfiting. Methanol production when DMDC contacts with the wine is the main drawback of this operation; the maximum addition of $200 \mathrm{mg} / \mathrm{L}$ of DMDC releases by hydrolysis $96 \mathrm{mg} / \mathrm{L}$ of methanol (EEC, 2019).
Bearing in mind the maximum acceptable limit of methanol in white wines of $250 \mathrm{mg} / \mathrm{L}$ (OIV, 2020), the contribute of DMDC seems not be of special concern (Divol et al., 2005).

\section{Oenological tannins}

As aforementioned, even though laccase activity is reduced at the final stage of infection, the possibility of oxidizing phenolic compounds in the must is still high. In order to further suppress this enzyme along with sulfur dioxide, addition of oenological tannins before ALF, especially skin/seed tannins and gallotannins, is an efficient treatment - Figure 3 (Vignault et al., 2020). Exogenous tannins when added in the medium, due to hydrogen bonds and van der Waals forces formed, combine and precipitate with proteins, including enzymes such as laccase, helping indirectly protein stabilization. They also act as antioxidants (Moreno and Peinado, 2012).

\section{Protein stabilization}

\section{Bentonite}

Bentonite addition in noble rot must does not stabilize the medium from protein hazes during ALF and does not make easier the racking afterwards, since the amount of protective colloids such as glucans is at maximum levels at this time (Ribéreau-Gayon et al., 2006a). In the case of fermenting must in barrels and age on lees, addition of bentonite after ALF is also not suitable. Contradictory to dry white wines, in botrytized wines addition of bentonite at this stage does not improve settling (Ribéreau-Gayon et al., 2006a). Bentonite is used before bottling, when part of glucans has been eliminated by precipitation during aging, and only after conducting stability trials (Figure 3). As a fining agent, bentonite along with barrel aging and filtration reduce wine turbidity at desired levels (Ribéreau-Gayon et al., 2006a).

\section{Stabilization with silica}

Another possible stabilization treatment to prevent protein turbidity in noble rot wines is the addition of siliceous earth, kieselsol or klebosol (Moreno and Peinado, 2012). It is an adsorbent treatment, like in bentonite case, where the dissociation of hydroxyl groups in an alkaline solution charges negatively the molecules, making possible their combination with the positively charged proteins, at wine $\mathrm{pH}$, due to their high Isoelectric Point (IP) (Moreno and Peinado, 2012). This fining agent is active even in difficult mediums with high quantity of protective colloids, such as $\beta$-glucans, that make clarification very laborious. For this reason, silica is considered suitable for noble rot musts and wines (Moreno and Peinado, 2012). In the form of alkaline solution of $30 \%$, the 
recommended dose is between 25 and $100 \mathrm{~mL} / \mathrm{hL}$ (Moreno and Peinado, 2012). For optimum results, better flocculation and settling, especially during barrel aging, it should be used in association with gelatin at a ratio 10:5 in favor of the silica - Figure 3 (Jackson, 2008). Silica should be added first to the medium, while both should stay in the wine for an optimum time of 14 days before racking (Moreno and Peinado, 2012).

\section{Tartrate stabilization}

Stabilization by cooling is actually ineffective in botrytized wines, while stability trials with oxalic acid can indicate potential future problems due to its easy crystallization with calcium cations (Ribéreau-Gayon et al., 2006b). Glucans as protective colloids can act sufficiently against tartaric crystallization. Effectiveness of the applied stabilization method should be estimated after six days at $-8{ }^{\circ} \mathrm{C}$ for this complex wine matrix (Moreno and Peinado, 2012).

\section{Clarification treatments}

\section{Filtration}

Wines produced from grapes affected by noble rot are difficult to clarify due to the high concentration of glucans that act as clogging colloids (Ribéreau-Gayon et al., 2006b). Aging process along with glucanases addition reduce glucans and wine turbidity below 60 NTU. As a result, the use of diatomaceous earth with medium size kieselguhr for polishing filtration is possible. After filtration, turbidity below 1 NTU is guaranteed for no longer than one week (RibéreauGayon et al., 2006b). During this period and just before bottling, fine sheet filtration, where the sheet consists of cellulose matrix with kieselguhr and perlite, and membrane filtration for total sterilization of the medium is applicable (Figure 3). Sterilization of the equipment before and after every filtration reduces the possibility of refermentation during storage (Ribéreau-Gayon et al., 2006b).

Addition of beta-glucanases ( $\beta 1-3, \beta 1-6)$

Beta-glucanases are very expensive enzymes able to hydrolyze $\beta$-glucans to glucose in order to avoid clogging problems during filtration. These enzymes are active up to $80 \%$ under an optimal temperature at around $40{ }^{\circ} \mathrm{C}$, and at wine $\mathrm{pH}$ between 3.1 and 3.6. Total sulfur dioxide at $200 \mathrm{mg} / \mathrm{L}$ after "mutage" does not affect their enzymatic activity (Dubourdieu et al., 1981). Taking into account that yeasts cell walls consist of glucans and mannoproteins, addition of the enzymes is advisable to be done after ALF to avoid fermentation problems - Figure 3 (Carrascosa et al., 2011). In any case, mannoproteins liberation in the medium can be beneficial for both protein and tartrate stabilization and improvement of organoleptic characteristics, explaining why these enzymes can also be used in other types of wines even without glucans presence (Waterhouse et al., 2016). The maximum acceptable limit of glucanases addition is 3 $\mathrm{g} / \mathrm{hL}$ (EEC, 2009).

\section{Treatments to avoid for noble rot wines}

\section{Inoculation of lactic acid bacteria}

Lactic acid bacteria, such as Oenococcus oeni, are used for conducting malolactic fermentation (MLF) (Jackson, 2008). Inhibition of these bacteria can be achieved by the presence of free sulfur dioxide at quantities higher than $20 \mathrm{mg} / \mathrm{L}$. Given that MLF is not desired for botrytized wines, because decrease of acidity will unbalance the wine by making it flabbier, their inoculation in wine is avoided (Jackson, 2008).

\section{Carboxymethylcellulose}

Carboxymethylcellulose (CMC) is a polar cellulose derivative, characterized by an electronegative charge, binding potassium tartrate crystals (electropositive charged), preventing their growth and precipitation (Moreno and Peinado, 2012; Pittari et al., 2018). CMC efficiency in terms of time is limited as it cannot prevent the precipitation of calcium tartrate that generally occurs in wine after several years' aging. Given that CMC should only be used for wines without aging potentials destined to be consumed young, it is not recommended for the tartrate stabilization of botrytized wines (Moreno and Peinado, 2012).

\section{Ascorbic acid}

Ascorbic acid is an additive used before bottling to protect wines from oxidation. It is an antioxidant that acts against oxygen faster than sulfur dioxide, and it is mainly added in young white or rosé wines without aging potentials (Waterhouse et al., 2016). The aromatic profile of these wines (fruity aromas) is based on the primary aromas of the grape varieties, the conservation of which is only possible under the absence of oxygen (Moreno-Arribas and Polo, 2009). The wine matrix of noble rot wines is totally different because it is already highly oxidized during botrytization, and in most of the cases these wines are passing through a period of barrel aging so the aromatic profile is mainly based on secondary and tertiary aromas. Given that the corresponding volatile compounds are stable in oxidative environment, the use of ascorbic acid is not necessary (Moreno-Arribas and Polo, 2009). 


\section{Wine aging \\ Barrel aging}

The most iconic noble rot wines are aged from 16 to 24 months in oak barrels (Ribéreau-Gayon et al., 2006a). The aging starts 15 days after "mutage" and each barrel is topped up very carefully once per week in the highest possible aseptic way. Given that possibility of refermentation is always high, it must always be taken under consideration by the winemaker. For wines fermented in vats, the first racking is carried out after the end of fermentation to eliminate yeasts still present in the wine. It is desirable that only fine lees remain in the wine to avoid production of reductive notes by sulfur reductase (Ribéreau-Gayon et al., 2006a). For wines fermented in barrels, the first racking takes place during winter due to cold weather, while only fine lees remain in wine at that time. Finally, the last two rackings are done within the next six months - Figure 3 (Ribéreau-Gayon et al., 2006a). During each racking practice barrels must be properly cleaned and treated with sulfur prior to reuse. Racking should always be a very delicate treatment in order to limit extended oxidation, preventing ethanal's formation that has very powerful affinity with sulfur dioxide. Decrease of free sulfur dioxide level always increases the instabilities of this type of wines (Ribéreau-Gayon et al., 2006a).

Barrel aging is required for the evolution of the tertiary aromas. During this stage, flavors of dried or artificial fruits like apricot, quince, peach and grapefruit, honey, almonds and notes of wood are either intensified or developed (Ribéreau-Gayon et al., 2006a). The exact physicochemical evolution of these wines during barrel aging is still not well clarified and studied.

\section{Bottling aging}

A study on how aroma compounds were evolved during bottle aging of Sauternes wines revealed the total elimination of volatile thiols present in young botrytized wines except for 3MH (Bailly et al., 2009). The concentration of this odorant compound can be even 50 times higher than its perception threshold even after six years of bottle aging (Bailly et al., 2009). Furthermore, aromas from botrytization process, such as sotolon and others resulting from other 2-furanone derivatives, along with secondary aromas produced by fermentation like higher alcohols, and wood aged aromas deriving from barrel maturation, were still present in lower concentrations but still perceivable, in the samples. Finally, a furanone derivative known as abhexon, with honey and spicy flavor, was quantified at levels close to its perception threshold of $7 \mu \mathrm{g} / \mathrm{L}$ after six years of bottle aging (Bailly et al., 2009).

\section{WINE SAFETY}

\section{Mycotoxins}

Ochratoxin A (OTA) is a mycotoxin known for its toxic properties on living organisms (Purchase and Theron, 1968). In foods and fruits, including grapes and wines, it is present as a result of fungus infection, due to the metabolic pathways mainly of Aspergillus and Penicillium spp. (Purchase and Theron, 1968). Due to its toxic effect on human body, OTA's maximum acceptable level in wines is $2.0 \mu \mathrm{g} / \mathrm{kg}$ (EEC, 2006). Some types of wines are exempted from this regulation, but noble rot wines are not included in this group. Part of the botrytization process includes the simultaneous colonization of $B$. cinerea with other microbial on berries. Therefore, these wines are prone to potential contamination. In a study conducted on different noble rot wines derived from different regions across Europe, OTA was not identified in the samples analyzed (Valero et al., 2008). What was proposed but it has not been proved yet, is that even if a small amount of OTA is produced by other microorganisms during infection, its degradation by $B$. cinerea is possible. The same trend of botrytized wines was followed in the case of icewines or late harvest sweet wines. On the contrary, toxin's content in sweet wines made of grapes left to dry in the sun was the highest (Mateo et al., 2007; Valero et al., 2008).

\section{Biogenic amines}

Biogenic amines are toxic compounds that derive from decarboxylation of amino-acids under the enzymatic activity of decarboxylase (Bauza et al., 1995). The origin of this enzyme is mainly correlated with microorganisms' presence in berries, such as $B$. cinerea, or in wines, such as lactic acid bacteria. Either way, a small amount is always produced by yeasts during alcoholic fermentation (Bauza et al., 1995). The average values in wine vary from 1 to 2 $\mathrm{mg} / \mathrm{L}$, while when exceeds $10 \mathrm{mg} / \mathrm{L}$, it can be harmful for allergic consumers. The most plentiful and important biogenic amines found in wines are histamine, tyramine, putrescine, cadaverine, phenylethylamine and isoamylamine (Bauza et al., 1995). A study carried out on different types of wine showed that the levels of these amines were higher in noble rot wines than in the dry ones (Kiss and SassKiss, 2005). Up to 13 biogenic amines were identified in botrytized wines; concentrations much higher than $1 \mathrm{mg} / \mathrm{L}$ were found for phenylethylamine, putrescine and tyramine. Phenylethylamine and agmatine were 
connected with $B$. cinerea, while tyramine was correlated with fermentation and other winemaking techniques (Kiss and Sass-Kiss, 2005).

Concerning the amount of free amino-acids and biogenic amines in Tokaji Aszú wines, some studies indicated tyramine, putrescine and histamine as the main biogenic amines with a total content of $24 \mathrm{mg} / \mathrm{L}$ (Csomós and Simon-Sarkadi, 2002). The argue that botrytization changed the biogenic amines profile both on grapes and wine was supported by Hajós et al. (2000), who also highlighted that these amines' concentrations increased during aging. Finally, except for botrytization, other factors such as vintage, region, weather and winemaking practices need to be taken into consideration (Hajós et al., 2000; Sass-Kiss et al., 2000; Csomós and Simon-Sarkadi, 2002).

\section{CONCLUSIONS}

Botrytized wines are very interesting in every aspect of winemaking, starting from grape to bottle. $B$. cinerea plays a critical role in their quality by changing all the chemical characteristics of berries and musts. The techniques used for the production of these wines show remarkable particularities. Even though these are wines produced for many years and well established in the market, systematic studying upon them, with the slight exception of Sauternes and Tokaji Aszú wines, is not as evolved as expected.

Earlier studies were focused on the direct effects of the fungus on berries and musts and tried to propose sustainable practices during winemaking. In contrast, current studies are searching for the activity of $B$. cinerea's genome and how it affects berry's transcription factors that lead to specific metabolic pathways. Further research is needed to understand the behavior of sulfur dioxide in the complex matrix of noble rot wines in order to reduce its additions by proposing alternatives. It is vital for noble rot wine industry to adapt to the current marketing trends, since consumers are searching for more and more "healthier" wines with limited sulfur dioxide and ethanol content.

The aromatic profile of these wines is a subtopic studied in depth. On the contrary, wine's chemical evolution and oxygen participation during barrel and bottle aging need further investigation. The importance of climate change that might lead to problematic botrytization and whether or not artificial induction of $B$. cinerea is possible is a very controversial topic that also needs further discuss. The complex combination of many factors to produce noble rot wines, starting from the obligation of having very specific environmental conditions, explains the rarity of noble rot occurrence and highlights the uniqueness of the final product.

\section{ACKNOWLEDGMENTS}

This work was supported by the Portuguese National Funding Agency for Science and Technology [LEAF (UID/AGR/04129/2020); 57/2016/CP1382/CT0025].

\section{REFERENCES}

Agenis-Nevers M., 2006. Impacts du changement climatique sur les activités viti-vinicoles. Observatoire National sur les Effects du Réchauffement Climatique (ONERC), Report No 3, Paris.

Bailly S., Jerkovic V., Marchand-Brynaert J., Collin S., 2006. Aroma extraction dilution analysis of Sauternes wines. Key role of polyfunctional thiols. J. Agric. Food Chem., 54, 7227-7234.

Bailly S., Jerkovic V., Meurée A., Timmermans A., Collin S., 2009. Fate of key odorants in Sauternes wines through aging. $J$. Agric. Food Chem., 57, 8557-8563.

Banerjee N., Bhatnagar R., Viswanathan L., 1981. Inhibition of glycolysis by furfural in Saccharomyces cerevisiae. European $J$. Appl. Microbiol. Biotechnol., 11, 226-228.

Barbe J-C., De Revel G., Joyeux A., Lonvaud-Funel A., Bertrand A., 2000. Role of carbonyl compounds in $\mathrm{SO}_{2}$ binding phenomena in musts and wines from botrytized grapes. J. Agric. Food Chem., 48, 3413-3419.

Barbe J.-C., De Revel G., Joyeux A., Bertrand A., Lonvaud-Funel A., 2001. Role of botrytized grape micro-organisms in $\mathrm{SO}_{2}$ binding phenomena. J. Appl. Microbiol., 90, 34-42.

Bauza T., Blaise A., Daumas F., Cabanis J.C., 1995. Determination of biogenic amines and their precursor amino acids in wines of the Vallée du Rhône by high-performance liquid chromatography with precolumn derivatization and fluorimetric detection. $J$. Chromatogr. A, 707, 373-379.

Bely M., Rinaldi A., Dubourdieu D., 2003. Influence of assimilable nitrogen on volatile acidity production by Saccharomyces cerevisiae during high sugar fermentation. J. Biosci. Bioeng., 96, 507-512.

Bely M., Stoeckle P., Masneuf-Pomarède I., Dubourdieu D., 2008. Impact of mixed Torulaspora delbrueckii - Saccharomyces cerevisiae culture on high-sugar fermentation. Int. J. Food Microbiol., 122, 312-320.

Bisson L.F., 1999. Stuck and sluggish fermentations. Am. J. Enol. Vitic., 50, 107-119.

Blanco-Ulate B., Amrine K.C.H., Collins T.S., Rivero R.M., Vicente A.R., Morales-Cruz A., Doyle C.L., Ye Z., Allen G., Heymann H., Ebeler S.E., Cantu D., 2015. Developmental and metabolic plasticity of white-skinned grape berries in response to Botrytis cinerea during noble rot. J. Plant Physiol., 169, 24222443.

Bock G., Benda I., Schreier P., 1988. Microbial transformation of geraniol and nerol by Botrytis cinerea. Appl. Microbiol. Biotechnol., 27, 351-357.

Bonnefoy C., Quénol H., Barbeau G., Madelin M., 2010. Analyse climatique à l'échelle des Coteaux du Layon. In: VIII International Terroir Congress. 109-114. Soave. 
Boulton R.B., Singleton V.L., Bisson L.F., Kunkee R.E., 1999. Principles and practices of winemaking. 604 p. Springer, Boston.

Carbajal-Ida D., Maury C., Salas E., Siret R., Mehinagic E., 2016. Physico-chemical properties of botrytized Chenin Blanc grapes to assess the extent of noble rot. Eur. Food Res Technol., 242, 117126.

Carbonneau A., Casteran P., 1986. Essai de systèmes de conduite de la vigne pour la production de raisins «pourris nobles» en bordelais. Connaiss. Vigne Vin, 20, 17-38.

Carrascosa A.V., Muñoz R., González R., 2011. Molecular wine microbiology. 363 p. Academic Press, London.

Chen J.Y., Wen P.F., Kong W.F., Pan Q.H., Wan S.B., Huang W.D., 2006. Changes and subcellular localizations of the enzymes involved in phenylpropanoid metabolism during grape berry development. J. Plant Physiol., 163, 115-127.

Ciani M., Ferraro, L., 1996. Enhanced glycerol content in wines made with immobilized Candida stellata cells. Appl. Environ. Microbiol., 62, 128-132.

Ciani M., Ferraro L., 1998. Combined use of immobilized Candida stellata cells and Saccharomyces cerevisiae to improve the quality of wines. J. Appl. Microbiol., 85, 247-254.

Ciani M., Ferraro L., Fatichenti F., 2000. Influence of glycerol production on the aerobic and anaerobic growth of the wine yeast Candida stellata. Enzyme Microb. Technol., 27, 698-703.

Cichewicz R.H., Kouzi S.A., Hamann M.T., 2000. Dimerization of resveratrol by the grapevine pathogen Botrytis cinerea. J. Nat. Prod., 63, 29-33.

Cooke R.C., Capone D.L., van Leeuwen K.A., Elsey G.M., Sefton M.A., 2009. Quantification of several 4-alkyl substituted $\gamma$ lactones in Australian wines. J. Agric. Food Chem., 57, 348-352.

Csomós E., Simon-Sarkadi L., 2002. Characterisation of Tokaj wines based on free amino acids and biogenic amines using ionexchange chromatography. Chromatographia, 56, 185-188.

Cuadrado M.U., Pérez-Juan P.M., Castro M.D.L., Gómez-Nieto M.A., 2005. A fully automated method for in real time determination of laccase activity in wines. Anal. Chim. Acta, 553, 99-104.

Divol B., Strehaiano P., Lonvaud-Funel A., 2005. Effectiveness of dimethyldicarbonate to stop alcoholic fermentation in wine. Food Microbiol., 22, 169-178.

Donèche B., 1989. Carbohydrate metabolism and gluconic acid synthesis by Botrytis cinerea. Can. J. Bot., 67, 2888-2893.

Donèche B., 1991. Influence des sucres sur la laccase de Botrytis cinerea dans le cas de la pourriture noble du raisin. J. Int. Sci. Vigne Vin, 25, 111-115.

Dubernet M., Ribéreau-Gayon P., Lerner H.R., Harel E., Mayer A.M., 1977. Purification and properties of laccase from Botrytis cinerea. Phytochemistry, 16, 191-193.

Dubourdieu D., Villettaz J.C., Desplanques C., Ribéreau-Gayon P., 1981. Dégradation enzymatique du glucane de Botrytis cinerea application à l'amélioration de la clarification des vins issus de raisins pourris. Connaiss. Vigne Vin, 15, 161-177.

EEC, 2006. Regulation (EEC) No 1881/2006 of 19-12-2006, Official Journal of the European Union, 20 December 2006.

EEC, 2009. Regulation (EEC) No 606/2009 of 10-07-2009, Official Journal of the European Union, 24 July 2009.

EEC, 2013. Regulation (EEC) No 1308/2013 of 17-12-2013, Official Journal of the European Union, 20 December 2013.
EEC, 2019. Regulation (EEC) No 2019/934 of 12-03-2019, Official Journal of the European Union, 07 June 2019.

Fedrizzi B., Tosi E., Simonato B., Finato F., Cipriani M., Caramia G., Zapparoli G., 2011. Changes in wine aroma composition according to botrytized berry percentage: A preliminary study on Amarone wine. Food Technol. Biotechnol., 49, 529-535.

Ferreira B., Hory C., Bard M.H., Taisant C., Olsson A., Le Fur Y, 1995. Effects of skin contact and settling on the level of the C18:2, C18:3 fatty acids and C6 compounds in Burgundy Chardonnay musts and wines. Food Qual. Prefer., 6, 35-41.

Ferreira A.C.S, Barbe J-C., Bertrand A., 2003. 3-Hydroxy-4,5dimethyl-2(5H)-furanone: A key odorant of the typical aroma of oxidative aged Port wine. J. Agric. Food Chem., 51, 4356-4363.

Fournier E., Gladieux P., Giraud T., 2013. The "Dr Jekyll and Mr Hyde fungus": Noble rot versus gray mold symptoms of Botrytis cinerea on grapes. Evol. Appl., 6, 960-969.

Frankel E.N., Kanner J., German J.B., Parks E., Kinsella J.E., 1993. Inhibition of oxidation of human low-density lipoprotein by phenolic substances in red wine. Lancet, 341, 454-457.

Garcia-Jares C.M., Médina B., 1997. Application of multivariate calibration to the simultaneous routine determination of ethanol, glycerol, fructose, glucose and total residual sugars in botrytizedgrape sweet wines by means of near-infrared reflectance spectroscopy. Fresen. J. Anal. Chem., 357, 86-91.

Girbau T., Stummer B.E., Pocock K.F., Baldock G.A., Scott E.S., Waters E.J., 2004. The effect of Uncinula necator (powdery mildew) and Botrytis cinerea infection of grapes on the levels of haze-forming pathogenesis-related proteins in grape juice and wine. Aust. J. Grape Wine R., 10, 125-133.

Goetghebeur M., Brun S., Galzy P., Nicolas M., 1993. Benzyl alcohol oxidase and laccase synthesis in Botrytis cinerea. Biosci. Biotech. Bioch., 57, 1380-1381.

Goetz G., Fkyerat A., Métais N., Kunz M., Tabacchi R., Pezet R., Pont V., 1999. Resistance factors to gray mold in grape berries: Identification of some phenolics inhibitors of Botrytis cinerea stilbene oxidase. Phytochemistry, 52, 759-767.

González-Álvarez M., Noguerol-Pato R., González-Barreiro C., Cancho-Grande B., Simal-Gándara J., 2014. Sensory description of sweet wines obtained by the winemaking procedures of raisining, botrytization and fortification. Food Chem., 145, 1021-1030.

Hajós G., Sass-Kiss A., Szerdahelyi E,. Bardocz S., 2000. Changes in biogenic amine content of Tokaj grapes, wines, and Aszu-wines. J. Food Sci., 65, 1142-1144.

Hart J.H., 1981. Role of phytostilbenes in decay and disease resistance. Ann. Rev. Phytopathol., 19, 437-458.

Jackson R.S., 2008. Wine science principles and applications. 751 p. Academic Press, Burlington.

Jang M., Cai L., Udeani G.O., Slowing K.V., Cathy F.T., Beecher C.W.W., Fong H.H.S., Farnsworth N.R., Kinghorn A.D., Mehta R.G., Moon R.C., Pezzuto J.M., 1997. Cancer chemopreventive activity of resveratrol, a natural product derived from grapes. Sience, 275, 218-220.

Joyeux A., Lafon-Lafourcade S., Ribéreau-Gayon P., 1984. Evolution of acetic acid bacteria during fermentation and storage of wine. Appl. Environ. Microbiol., 48, 153-156.

Kamoen O., 1992. Botrytis cinerea: Host-pahtogen interactions', In: 10th International Botrytis symposium. 39-47. Wageningen.

Keller M., 2015. The science of grapevines. Anatomy and physiology. 509 p. Academic Press, London. 
Kikuchi T., Kadota S., Suehara H., Nishi A., Tsubaki K., Yano H., Harumaya K., 1983. Odorous metabolites of fungi, Chaetomium globosum Kinze ex Fr. and Botrytis cinerea Pers. ex Fr., and a blue-green alga, Phormidium tenue (Meneghini) Gomont. Chem. Pharm. Bull., 34, 659-663.

Kiss J., Sass-Kiss A., 2005. Protection of originality of Tokaji Aszú: Amines and organic acids in botrytized wines by highperformance liquid chromatography. J. Agric. Food Chem., 53, 10042-10050.

König H., Unden G., Fröhlich J., 2017. Biology of microorganisms on grapes, in must and in wine. 710 p. Springer, Cham.

Lafon-Lafourcade S., Ribéreau-Gayon P., 1979. Quelques observations sur les problèmes microbiologiques de la vinification en blanc. Connaiss. Vigne Vin, 33, 52-76.

Landrault N., Larronde F., Delaunay J.-C, Castagnino C., Vercauteren J., Merillon J.-M., Gasc F., Cros G., Teissedre P.-L., 2002. Levels of stilbene oligomers and astilbin in French varietal wines and in grapes during noble rot development. J. Agric. Food Chem., 50, 2046-2052.

Lorenzini M., Azzolini M., Tosi E., Zapparoli G., 2012. Postharvest grape infection of Botrytis cinerea and its interactions with other molds under withering conditions to produce noblerotten grapes. J. Appl. Microbiol., 114, 762-770.

Lorenzini M., Millioni R., Franchin C., Zapparoli G., Arrigoni G., Simonato B., 2015. Identification of potential protein markers of noble rot infected grapes. Food Chem., 179, 170-174.

Lovato A., Zenoni S., Tornielli G.B., Colombo T., Vandelle E., Polverari A., 2019. Specific molecular interactions between Vitis Vinifera and Botrytis cinerea are required for noble rot development in grape berries. Postharvest Biol. Tec., 156, 1-15.

Magyar I., 2011. Botrytized Wines. In: Advances in Food and Nutrition Research, Volume 63. 147-206. Jackson R.S. (ed.), Academic Press, Burlington.

Magyar I., Tóth T., 2011. Comparative evaluation of some oenological properties in wine strains of Candida stellata, Candida zemplinina, Saccharomyces uvarum and Saccharomyces cerevisiae. Food Microbiol., 28, 94-100.

Marchal R., Warchol M., Cilindre C., Jeandet P., 2006. Evidence for protein degradation by Botrytis cinerea and relationships with alteration of synthetic wine foaming properties. J. Agr. Food Chem., 54, 5157-5165.

Masneuf I., Dubourdieu D., 2000. Rôle de la souche de levure sur les combinaisons du dioxyde de soufre des vins issus de raisins botrytisés et passerillés. J. Int. Sci. Vigne Vin, 34, 27-31.

Masuda M., Okawa E.-I-C., Nishimura K.-I-C., Yunome H., 1984. Identification of 4,5-dimethil-3-hydroxy-2(5H)- furanone (sotolon) and ethyl 9-hydroxynonanoate in botrytized wine and evaluation of the roles of compounds characteristic of it. Agric. Biol. Chem., 48 , 2707-2710

Mateo R., Medina Á., Mateo E.M., Mateo F., Jiménez M., 2007. An overview of ochratoxin A in beer and wine. Int. J. Food. Microbiol., 119, 79-83.

Miklósy É., Kalmár Z., Kerényi Z., 2004. Identification of some characteristic aroma compounds in noble rotted grape berries and Aszú wines from Tokaj by GC-MS. Acta Aliment., 33, 215-226.

Miklósy É., Kerényi Z., 2004. Comparison of the volatile aroma components in noble rotted grape berries from two different locations of the Tokaj wine district in Hungary. Anal. Chim. Acta, 513, 177-181.
Mills D.A., Johannsen E.A., Cocolin L., 2002. Yeast diversity and persistence in Botrytis-affected wine fermentations. Appl. Environ. Microbiol., 68, 4884-4893.

Moreno-Arribas M.V., Polo M.C., 2009. Wine chemistry and biochemistry. 735 p. Springer, New York.

Moreno J., Peinado R., 2012. Enological chemistry. 429 p. Academic Press, London.

Negri S., Lovato A., Boscaini F., Salvetti E., Torriani S., Commisso M., Danzi R., Ugliano M., Polverari A., Tornielli G.B., Guzzo F., 2017. The induction of noble rot (Botrytis cinerea) infection during postharvest withering changes the metabolome of grapevine berries (Vitis Vinifera L., cv. Garganega). Front. Plant Sci., 8, 1-12.

OIV, 2020. International code of oenological practices. $427 \mathrm{p}$ International Organisation of Vine and Wine, Paris.

Pittari E., Catarino S., Andrade M.C., Ricardo-da-Silva JM., 2018. Preliminary results on tartaric stabilization of red wine by adding different carboxymethylcelluloses. Ciência Téc. Vitiv., 33, 47-57.

Pucheu-Planté B., Seguin G., 1978. Pourriture vulgaire et pourriture noble en Bordelais. Connaiss. Vigne Vin, 12, 21-34.

Pucheu-Planté B., Seguin G., 1981. Influence des facteurs naturels sur la maturation et la surmaturation du raisin dans le Sauternais, en 1978 et 1979. Connaiss. Vigne Vin, 15, 143-160.

Pucheu-Planté B., Mercier M., 1983. Etude ultrastructurale de l'interrelation hôte-parasite entre le raisin et le champignon Botrytis cinerea: Exemple de la pourriture noble en Sauternais. Can. J. Bot., 61, 1785-1797.

Purchase I.F.H., Theron J.J., 1968. The acute toxicity of Ochratoxin A to rats. Food Chem. Toxicol., 6, 479-483.

Quideau S., Feldman K.S., Appel H.M., 1995. Chemistry of galloyl-derived $o$-quinones: Reactivity toward nucleophiles. J. Org. Chem., 60, 4982-4983.

Rantsiou K., Dolci P., Giacosa S., Torchio F., Tofalo R., Torriani S., Suzzi G., Rolle L., Cocolin L., 2012. Candida zemplinina can reduce acetic acid produced by Saccharomyces cerevisiae in sweet wine fermentations. Appl. Environ. Microbiol., 78, 1987-1994.

Ravji G.R., Rodriguez S.B., Thornton R.J., 1988. Glycerol production by four common grape molds. Am. J. Enol. Vitic., 39, $77-82$.

Reynolds A.G., 2010. Managing wine quality. Volume 2 Oenology and wine quality. 651 p. Woodhead Publishing Limited, Cambridge.

Ribéreau-Gayon P., 1982. Incidences oenologiques de la pourriture du raisin. Bull. OEPP, 12, 201-214.

Ribéreau-Gayon P., Dubourdieu D., Donèche B., Lonvaud A., 2006a. Handbook of Enology. Volume 1: The microbiology of wine and vinifications $2^{\text {nd }}$ edition. 497 p. John Wiley \& Sons, Chichester.

Ribéreau-Gayon P., Glories Y., Maujean A., Dubourdieu D., 2006b. Handbook of enology. Volume 2: The chemistry of wine stabilization and treatments $2^{\text {nd }}$ edition. 441 p. John Wiley \& Sons, Chichester.

Rolle L., Giordano M., Giacosa S., Vincenzi S., Segade S.R., Torchio F., Perrone B., Gerbi V., 2012. CIEL*a*b* parameters of white dehydrated grapes as quality markers according to chemical composition, volatile profile and mechanical properties. Anal. Chim. Acta, 732, 105-113. 
Rousseau S., Donèche B., 2001. Effects of water activity $\left(\mathrm{a}_{\mathrm{w}}\right)$ on the growth of some epiphytic micro-organisms isolated from grape berry. Vitis, $\mathbf{4 0}, \mathbf{7 5 - 7 8}$

Salgues M., Cheynier V., Gunata Z., Wylde R., 1986. Oxidation of grape juice $2-S$-glutathionyl caffeoyl tartaric acid by Botrytis cinerea laccase and characterization of a new substance : 2,5 - di S - GlutathionyI caffeoyl tartaric acid. J. Food Sci., 51, 1191-1194.

Sarrazin E., Dubourdieu D., Darriet P., 2007. Characterization of key-aroma compounds of botrytized wines, influence of grape botrytization. Food Chem., 103, 536-545.

Sarrazin E., Shinkaruk S., Tominaga T., Bennetau B., Frérot E., Dubourdieu D., 2007. Odorous impact of volatile thiols on the aroma of young botrytized sweet wines: Identification and quantification of new sulfanyl alcohols. J. Agric. Food Chem., 55, 1437-1444.

Sarrazin E., 2008. Recherches sur l'arôme des vins liquoreux de pourriture noble issus des cépages Sémillon et Sauvignon Blanc. Caractérisation de composés clés et étude de leur genèse. In: Grand Prix de L'Académie Amorim. Paris.

Sarrazin E., Shinkaruk S., Pons M., Thibon C., Bennetau B., Darriet P., 2010. Elucidation of the 1,3-sulfanylalcohol oxidation mechanism: An unusual identification of the disulfide of 3sulfanylhexanol in Sauternes botrytized wines. J. Agric. Food Chem., 58, 10606-10613.

Sass-Kiss A., Szerdahelyi E., Haj., 2000. Study of biologically active amines in grapes and wines by HPLC. Chromatographia, 51, 316-320.

Serrano-Ruiz J.C., Campelo J.M., Francavilla M., Romero A..A, Luque R., Menéndez-Vázquez C., García A.B., García-Suárez E.J., 2012. Efficient microwave-assisted production of furfural from $\mathrm{C} 5$ sugars in aqueous media catalysed by Brönsted acidic ionic liquids. Catal. Sci. Technol., 2, 1828-1832.

Sipiczki M., 2004. Species identification and comparative molecular and physiological analysis of Candida zemplinina and Candida stellata. J. Basic. Microbiol., 44, 471-479.

Soden A., Francis I.L., Oakey H., Henschke P.A., 2000. Effects of co-fermentation with Candida stellata and Saccharomyces cerevisiae on the aroma and composition of Chardonnay wine. Aust. J. Grape Wine R., 6, 21-30.

Stamatopoulos P., Frérot E., Tempère S., Pons A., Darriet P., 2015. Contribution à l'étude de l'arôme de fruits confits dans les vins liquoreux de pourriture noble. Mise en évidence d'un «accord aromatique » impliquant des composés clés. Rev. Enologues, 156, 49-52.

Sudraud P., Chauvet S., 1985. Activité antilevure de l'anhydride sulfureux moléculaire. Connaiss. Vigne Vin, 19, 31-40.

Swiegers, J.H., Bartowsky E.J., Henschke P.A., Pretorius I.S., 2005. Yeast and bacterial modulation of wine aroma and flavour. Aust. J. Grape Wine R., 11, 139-173

Thakur N.S., 2018. Botrytized wines: A review. Intl. J. Food Ferment. Technol., 8, 1-13.

Thibon C., Dubourdieu D., Darriet P., Tominaga T., 2009. Impact of noble rot on the aroma precursor of 3-sulfanylhexanol content in Vitis Vinifera L. cv Sauvignon Blanc and Semillon grape juice. Food Chem., 114, 1359-1364.

Tominaga T., Niclass Y., Frérot E., Dubourdieu D., 2006. Stereoisomeric distribution of 3-mercaptohexan-1-ol and 3mercaptohexyl acetate in dry and sweet white wines made from Vitis Vinifera (var. Sauvignon Blanc and Semillon). J. Agr. Food Chem., 54, 7251-7255.
Tosi E., Fedrizzi B., Azzolini M., Finato F., Simonato B., Zapparoli G., 2012. Effects of noble rot on must composition and aroma profile of Amarone wine produced by the traditional grape withering protocol. Food Chem., 130, 370-375.

Tóth-Markus M., Magyar I., Kardos K., Bánszky L., Maráz A., 2002. Study of Tokaji Aszú wine flavour by solid phase microextraction method. Acta Aliment., 31, 343-354.

Valero A., Marín S., Ramos A.J., Sanchis V., 2008. Survey: Ochratoxin A in European special wines. Food Chem., 108, 593599.

Vignault A., Gombau J., Jourdes M, Moine V., Canals J.M., Fermaud M., Roudet J., Zamora F., Teissedre P.-L., 2020. Oenological tannins to prevent Botrytis cinerea damage in grapes and musts: Kinetics and electrophoresis characterization of laccase. Food Chem., 316, 1-9.

Walker A.S., Gautier A., Confais J., Martinho D., Viaud M., Pêcheur P., Dupont J., Fournier E., 2011. Botrytis pseudocinerea, a new cryptic species causing gray mold in French vineyards in sympatry with Botrytis cinerea. Phytopathology, 101, 1433-1445.

Wang X., Tao Y., Wu Y., An R., Yue Z., 2017. Aroma compounds and characteristics of noble-rot wines of Chardonnay grapes artificially botrytized in the vineyard. Food Chem., 226, 41-50.

Waterhouse A.L., Sacks G.L., Jeffery D.W., 2016. Understanding wine chemistry. 443 p. John Wiley \& Sons, Chichester.

Weiberg A., Wang M., Lin F.-M., Zhao H., Zhang Z., Kaloshian I., Huang H.-D., Jin H., 2014. Fungal small RNAs suppress plant immunity by hijacking host RNA interference pathways. Science, 342, 118-123.

Williamson B., Tudzynski B., Tudzynski P., Van Kan J.A.L., 2007. Botrytis cinerea: The cause of gray mold disease. Mol. Plant Pathol., 8, 561-580. 